\title{
Dynamics of ammonia exchange with cut grassland: strategy and implementation of the GRAMINAE Integrated Experiment
}

\author{
M. A. Sutton ${ }^{1}$, E. Nemitz ${ }^{1}$, M. R. Theobald ${ }^{1}$, C. Milford ${ }^{1, *}$, J. R. Dorsey ${ }^{2}$, M. W. Gallagher ${ }^{2}$, A. Hensen ${ }^{3}$, \\ P. A. C. Jongejan ${ }^{3}$, J. W. Erisman ${ }^{3}$, M. Mattsson ${ }^{4, *}$, J. K. Schjoerring ${ }^{4}$, P. Cellier ${ }^{5}$, B. Loubet ${ }^{5}$, R. Roche ${ }^{5}$, A. Neftel $^{6}$, \\ B. Hermann ${ }^{6}$, S. K. Jones ${ }^{6,1}$, B. E. Lehman ${ }^{* * *}{ }^{\dagger}$, L. Horvath ${ }^{7}$, T. Weidinger ${ }^{8}$, K. Rajkai ${ }^{9}$, J. Burkhardt ${ }^{10}$, \\ F. J. Löpmeier ${ }^{11}$, and U. Daemmgen ${ }^{12}$ \\ ${ }^{1}$ Centre for Ecology and Hydrology (CEH), Edinburgh Research Station, Bush Estate, Penicuik, Midlothian, EH26 0QB, UK \\ ${ }^{2}$ University of Manchester (UoM), Oxford Road, Manchester, M13 9PL, UK \\ ${ }^{3}$ Energy research Centre of the Netherlands (ECN), Postbus 1, 1755 ZG Petten, The Netherlands \\ ${ }^{4}$ Plant and Soil Science Laboratory, University of Copenhagen (UoC), Faculty of Life Sciences, Thorvaldsensvej 40, 871 \\ Frederiksberg C, Copenhagen, Denmark \\ ${ }^{5}$ Institut National de la Recherche Agronomique (INRA), UMR Environnement et Grandes Cultures, Thiverval-Grignon, \\ 78850, France \\ ${ }^{6}$ Agroscope Reckenholz-Tänikon Research Station (formerly: FAL-CH; now: ART), Zürich-Reckenholz, \\ 8046 Zürich, Switzerland \\ ${ }^{7}$ Hungarian Meteorological Service (HMS), P.O. Box 391675 Budapest, Hungary (in association with the Forest Research \\ Institute (FRI) of Hungary), Hungay \\ ${ }^{8}$ Eötvös Loránd University (ELU), Dept. Meteorology, 1117 Budapest, Hungary \\ ${ }^{9}$ Research Institute of Soil Science and Agrochemistry of Hungary (RISSAC), Herman Ottó út 15, 1022 Budapest, Hungary \\ ${ }^{10}$ University of Bonn, Institute for Crop Science and Resource Conservation, INRES-PE, Karlrobert-Kreiten-Str. 13, 53115 \\ Bonn, Germany \\ ${ }^{11}$ Agrometeorological Research Station of Deutscher Wetterdienst (DVD), Bundesallee 50; 38116 Braunschweig, Germany \\ ${ }^{12}$ Institut fur Agrarokologie, Bundesforschungsanstalt fur Landwirtschaft (FAL), (now: the von Thunen Institute), \\ Bundesallee 50, 38116 Braunschweig, Germany \\ *now at: Institute of Earth Sciences "Jaume Almera”, CSIC, Lluis Solé i Sabarís, 08028, Barcelona, Spain \\ *** now at: Section for Economy \& Technology, Halmstad University, 30118 Sweden \\ ${ }^{* * * * *}$ formerly at: University of Bern, Hochschulstr. 4, 3012 Bern, Switzerland \\ 'deceased
}

\begin{abstract}
A major international experiment on ammonia $\left(\mathrm{NH}_{3}\right)$ biosphere-atmosphere exchange was conducted over intensively managed grassland at Braunschweig, Germany. The experimental strategy was developed to allow an integrated analysis of different features of $\mathrm{NH}_{3}$ exchange including: a) quantification of nearby emissions and advection effects, b) estimation of net $\mathrm{NH}_{3}$ fluxes with the canopy by a range of micrometeorological measurements, c) analysis of the sources and sinks of $\mathrm{NH}_{3}$ within the plant canopy, including soils and bioassay measurements, d) comparison of the effects of grassland management options on $\mathrm{NH}_{3}$ fluxes
\end{abstract}

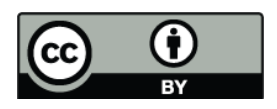

Correspondence to: $\mathrm{M}$. A. Sutton (ms@ceh.ac.uk) and e) assessment of the interactions of $\mathrm{NH}_{3}$ fluxes with aerosol exchange processes. Additional technical objectives included the inter-comparison of different estimates of sensible and latent heat fluxes, as well as continuous-gradient and Relaxed Eddy Accumulation (REA) systems for $\mathrm{NH}_{3}$ fluxes.

The prior analysis established the spatial and temporal design of the experiment, allowing significant synergy between these objectives. The measurements were made at 7 measurement locations, thereby quantifying horizontal and vertical profiles, and covered three phases: a) tall grass canopy prior to cutting (7 days), b) short grass after cutting (7 days) and c) re-growing sward following fertilization with ammonium nitrate (10 days). The sequential management treatments allowed comparison of sources-sinks, advection and aerosol interactions under a wide range of $\mathrm{NH}_{3}$ fluxes.

Published by Copernicus Publications on behalf of the European Geosciences Union. 
This paper describes the experimental strategy and reports the grassland management history, soils, environmental conditions and air chemistry during the experiment, finally summarizing how the results are coordinated in the accompanying series of papers.

\section{Introduction}

Atmospheric ammonia $\left(\mathrm{NH}_{3}\right)$ is a trace pollutant that has major impacts on terrestrial ecosystems and on the formation of secondary particulate matter. In the atmosphere, ammonia acts as a base, reacting to form ammonium $\left(\mathrm{NH}_{4}^{+}\right)$aerosol. By contrast, deposition of both forms of reduced nitrogen $\left(\mathrm{NH}_{\mathrm{x}}\right)$ can lead to soil acidification (e.g., van Breemen et al., 1982; Sutton et al., 1993c). In addition, $\mathrm{NH}_{\mathrm{x}}$ leads to ecological changes through eutrophication as well as through direct effects of gaseous $\mathrm{NH}_{3}$ (e.g., Achermann and Bobbink, 2003; Erisman et al., 2007; UNECE, 2007).

As a result of reductions in European emissions of sulphur and nitrogen oxides over the last decade, the relative importance of $\mathrm{NH}_{3}$ has grown substantially, so that it is estimated that $\mathrm{NH}_{3}$ will be the largest contributor to acidifying deposition in Europe in the next decade (Amman et al., 2005; Simpson et al. 2006). In addition, the role of $\mathrm{NH}_{3}$ as a precursor for secondary aerosol formation, with effects on human health, visibility and radiative forcing is increasingly being recognized (e.g., Adams et al., 2001; Vayenas et al., 2005; Sutton et al., 2007).

The exchange of $\mathrm{NH}_{3}$ between the land surface and the atmosphere has long been a key uncertainty in quantifying atmospheric budgets and nitrogen deposition (e.g., Eriksson, 1968; Söderlund and Svensson, 1976; Fowler et al., 1989; Langford et al., 1992; Sutton et al., 1993c, 1994; Hertel et al., 2006; Kugler et al., 2008). Biosphere-atmosphere exchange of $\mathrm{NH}_{3}$ is complicated by the existence of bi-directional fluxes for a wide range of land surfaces: the net flux at any time represents the combination of several opposing component fluxes, with leaf surfaces, leaf intercellular matrix, leaf litter and the soil surface (e.g., Denmead et al., 1978; Sutton et al., 1995a, b, 2000b, 2001a; Harper et al., 1996; Wyers and Erisman, 1998; Nemitz et al., 2000a, 2004a; Massad et al., 2008). These component fluxes are affected by a range of environmental, plant, soil and management factors, so that the overall $\mathrm{NH}_{3}$ flux for a given surface may switch between net emission and net deposition on sub-hourly, diurnal and seasonal scales.

Grasslands represent a major uncertainty in quantifying regional $\mathrm{NH}_{3}$ fluxes and parametrizing atmospheric models. This is both due to the large area extent of grasslands and because of the wide range of grassland types and management practices. In the context of bi-directional $\mathrm{NH}_{3}$ exchange, grasslands are of particular interest. Firstly, intensively managed grasslands are frequently net $\mathrm{NH}_{3}$ sources (e.g., Sutton et al., 1993b, 2001a; Bussink et al. 1995; Harper et al. 1996, Plantaz et al., 1997; Milford et al. 2001b; Daemmgen and Webb, 2005; Misselbrook et al., 2005; Kruit et al., 2007), resulting in grasslands impacting on atmospheric $\mathrm{NH}_{3}$ composition. Secondly, semi-natural grasslands are mainly net $\mathrm{NH}_{3}$ sinks (Duyzer et al., 1994; Sutton et al., 1993a; Flechard and Fowler, 1998; Spindler et al., 2001; Horváth et al., 2005), resulting in atmospheric $\mathrm{NH}_{3}$ impacting on the ecological functioning of grasslands.

Substantial progress has been made in quantifying these exchange processes for grasslands and other ecosystems, particularly through the work of major European Union research projects, such as EXAMINE (Sutton et al., 1995b, 2000b; Meixner et al., 1996; Schjoerring et al. 1998; Wyers and Erisman, 1998; Nemitz et al., 2004a) and the LIFE programme (Flechard and Fowler, 1998; Flechard et al., 1999; Erisman et al., 2001a; Spindler et al., 2001), as well as other international activities (Meyers et al., 2006; Trebs et al., 2006; Walker et al., 2006; Kruit et al., 2007; Sutton et al., 2007; Wolff et al., 2007; Neirynck and Ceulemans, 2008).

Complementing these efforts, the EU GRAMINAE (GRassland AMmonia INteractions Across Europe) project has provided a major assessment of the dynamics of $\mathrm{NH}_{3}$ fluxes with different European grassland types, including a wide network of both intensively managed and semi-natural grasslands (e.g., Sutton et al., 2001a, 2002; Milford et al., 2001a, b; Mosquera et al., 2001; Hill et al., 2001; Horváth et al., 2005; Loubet et al., 2001, 2002, 2006; Mattsson and Schjoerring, 2002, 2003; Riedo et al., 2002).

A limitation of such a dispersed network approach, however, is that it is not economically feasible to consider in an integrated way all of the interacting factors that affect $\mathrm{NH}_{3}$ exchange at all the individual measurement sites. As part of the GRAMINAE effort, a major experiment was therefore designed to consider the integration of different processes affecting $\mathrm{NH}_{3}$ exchange. The experiment took place at the German Federal Agricultural Research Centre Bundesforschungsanstalt für Landwirtschaft, (FAL) near Braunschweig in 2000, and linked micrometeorological, cuvette and bioassay analyses for $\mathrm{NH}_{3}$, gas-particle interactions, effects of management practice and the role of advection from agricultural sources on $\mathrm{NH}_{3}$ fluxes in the rural landscape. Overall, the experiment included fifty scientists in the field.

The present paper describes the objectives, strategy and implementation of the GRAMINAE Braunschweig Experiment. The method developments and prior modelling tasks necessary to refine the measurement strategy are summarized, followed by a description of the spatial and temporal design of the experiment, including the soil and meteorological conditions prevailing during the experiment. Finally, the paper outlines the inter-dependence of the detailed analyses arising from the experiment, and reflects on the merits and challenges of such an integrated approach. 


\section{Key questions and objectives}

The GRAMINAE Integrated Experiment addressed five major scientific questions:

1. How do the component sources and sinks of ammonia exchange (leaf surfaces, leaf tissues, plant uptake from soil, litter decomposition) integrate to control net fluxes with the atmosphere?

2. What are the mechanisms by which grassland management events (cutting and $N$ fertilization) affect component and net ammonia fluxes?

3. When does the location of a micrometeorological study site in a real landscape lead to quantifiable effects of advection on net ammonia fluxes and their measurement?

4. How much does the near-surface perturbation of the equilibria between ammonia, acid gases and aerosols lead to non-conservation of vertical ammonia fluxes, and is this a relevant mechanism for particle formation/growth?

5. To what extend can divergence in vertical ammonia fluxes (either due to advection or chemical reactions) be directly measured by available techniques?

All of these questions are closely linked. Although first attempts to measure $\mathrm{NH}_{3}$ fluxes by eddy covariance have been made (Shaw et al., 1998; Famulari et al., 2004; Whitehead et al., 2008), most studies have applied the aerodynamic gradient method (AGM), which is based on determination of the vertical concentration profile of $\mathrm{NH}_{3}$ above the canopy (e.g., Sutton et al., 1993a; Wyers and Erisman, 1993; Kruit et al., 2007; Neirynck and Ceulemans, 2008). The gradient method is not well suited to the quantification of divergence in the vertical flux (compared with the flux at the surface), since it estimates an average vertical flux based on measurements at different heights. Flux measurements methods that require sampling at a single height are therefore preferred (e.g., eddy covariance, EC; relaxed eddy accumulation, REA). Given the challenges for accurate $\mathrm{EC}$ measurements of $\mathrm{NH}_{3}$, a priority was identified to the application of REA for $\mathrm{NH}_{3}$, with the ultimate goal to deploy several REA systems at different heights and thereby directly measure vertical flux divergence (change in the flux with height) where this is significant.

Both advection of $\mathrm{NH}_{3}$ from nearby sources and reactions with acid gases are possible sources of flux divergence and can lead to errors in the determination of vertical fluxes using micrometeorological methods. The tendency in micrometeorological studies has been to try to avoid such effects through careful selection of field sites and experimental conditions. However, it often proves difficult to estimate the importance of advection and chemical interactions a priori. Advection from nearby sources is often thought to be of minor importance, as long as the flux footprint falls within the study area, while Loubet et al. $(2001,2006)$ have shown that downwind of ground-level $\mathrm{NH}_{3}$ point-sources, advection errors can be significant for several hundred metres. Similarly, Nemitz et al. (2004a, b) and Nemitz and Sutton (2004) showed that evaporation of $\mathrm{NH}_{4} \mathrm{NO}_{3}$ near the ground can alter $\mathrm{NH}_{3}$ exchange fluxes, even where this effect might be expected to be insignificant.

In addition, the conscious minimization of advection errors in the choice of field sites means that the "ideal" field sites typically selected by researchers are far from representative. By contrast, such non-stationarities are "real world" issues that need to be quantified rather than avoided. This is particularly relevant for $\mathrm{NH}_{3}$ where near-by agricultural point sources are often impossible to avoid in many European landscapes. Advection and chemistry effects are also of interest in their own right as processes that affect the net exchange of $\mathrm{NH}_{3}, \mathrm{HNO}_{3}$ and $\mathrm{NH}_{4}^{+}$containing aerosol (e.g. Brost et al., 1988; Milford et al., 2001a; Nemitz et al., 2004a, b; Nemitz and Sutton, 2004; Loubet et al., 2006). The GRAMINAE Braunschweig experiment was therefore designed to investigate the extent of vertical flux divergence due to advection and chemistry effects.

Finally, a core issue of $\mathrm{NH}_{3}$ bi-directional exchange is the quantification of how different component fluxes interact to generate net $\mathrm{NH}_{3}$ exchange. To understand these effects requires analysis of the interactions with plant physiology, litter dynamics and interactions with soil conditions. In particular, the vertical structure of a plant canopy can lead to an internal cycle, so that $\mathrm{NH}_{3}$ released from litter or the soil surface may be recaptured by overlaying leaves (Denmead et al., 1976; Nemitz et al., 2000a, b; Harper et al., 2000). The understanding of these interactions can be improved by the integration of above-canopy measurements of net $\mathrm{NH}_{3}$ exchange with cuvette measurements, bioassay determinations and analysis of within-canopy $\mathrm{NH}_{3}$ fluxes.

Based on the above concerns, the Primary Scientific Objectives were established as:

1. to measure the net exchange flux of $\mathrm{NH}_{3}$ over managed grassland using micrometeorological methods, quantifying the effect of cutting, nitrogen fertilization and environmental controls;

2. to apply bioassay measurements to estimate the foliar $\mathrm{NH}_{4}^{+}, \mathrm{pH}$ and related parameters and thereby to estimate foliar $\mathrm{NH}_{3}$ compensations point for different grass species and plant conditions;

3. to apply cuvette measurements to quantify the potential for $\mathrm{NH}_{3}$ emissions from foliage, drying or decomposing leaf litter;

4. to use a comparison of different management treatments with cuvette and bioassay measurements to improve the understanding of controls on $\mathrm{NH}_{3}$ fluxes; 
5. to integrate the quantification of component processes and fluxes in the canopy, including measurements of soil $\mathrm{N}$ availability/uptake, apoplastic $\mathrm{NH}_{4}^{+}$concentrations, and within-canopy source/sink distributions;

6. to quantify particle size-distributions, particle number fluxes and chemical fluxes of acid gases and inorganic aerosols;

7. to quantify the extent of chemical reactions of $\mathrm{NH}_{3}$ in the air within and immediately above the plant canopy to form or evaporate particulate matter, and to consider the consequence of this process for net $\mathrm{NH}_{3}$ and particle fluxes;

8. to quantify the interactions of $\mathrm{NH}_{3}$ fluxes with the chemistry of leaf surfaces wetted by dew or rain;

9. to determine horizontal concentration gradients of $\mathrm{NH}_{3}$ downwind of a farm source allowing quantification of the advection error in the vertical flux and analysis of the consequences for net $\mathrm{NH}_{3}$ fluxes;

10. to compare $\mathrm{NH}_{3}$ emissions from a farm source estimated by plume measurements and inverse dispersion modeling, as a basis to assess inventory-based emission estimates for cattle and pigs.

The Technical Objectives that provide the basis to address primary objectives included:

1. to inter-compare above-canopy estimates of turbulent exchange for momentum, sensible and latent heat, identifying the implications for sampling precision in situations without replication and providing robust estimates for this study;

2. to inter-compare estimates of $\mathrm{NH}_{3}$ fluxes derived from different continuous $\mathrm{NH}_{3}$ gradient methods, identifying the implications for un-replicated measurements and to provide a robust best-estimate of the net $\mathrm{NH}_{3}$ flux;

3. to evaluate and inter-compare several continuous REA systems for $\mathrm{NH}_{3}$ flux measurement and, if sufficiently precise, to deploy these to measure vertical flux divergence;

4. to determine the turbulent structure within the grass canopy and to quantify diffusive time-scales, comparing direct turbulence measurements with estimates derived from application of a Radon tracer method;

5. to develop and test a method for estimating total soluble nitrogen concentration of grass leaves as an estimate of "substrate nitrogen" for comparison with ecosystem model estimates;
6. to refine an approach to estimate farm-scale $\mathrm{NH}_{3}$ emissions (applied to the dairy and pig unit of the FAL) from fixed and mobile $\mathrm{NH}_{3}$ concentration measurements downwind of the farm coupled with inverse dispersion modelling.

These objectives relate both to the measurements and model development. Firstly, models were used as analysis tools to derive further measurement-based estimates, e.g., landscapescale inverse dispersion and advection modelling (Loubet et al., 2001, 2006), within-canopy inverse Lagrangian modelling (Nemitz et al., 2000a), modelling of gas-particle interactions (Nemitz and Sutton, 2004) and the calculation of in-canopy eddy diffusivities from Radon profiles (Lehmann et al., 1999). Secondly, other models were applied with basic site, management and environmental input data to compare with the measured results, e.g. soil-vegetation- atmospheretransfer (SVAT) modelling for $\mathrm{NH}_{3}$ net exchange (Sutton et al., 1995b, 1998; Flechard et al., 1999; Nemitz et al., 2001b), ecosystem modelling of $\mathrm{NH}_{3}$ exchange with grassland functioning (Riedo et al., 2002; Massad et al., 2008) and aerosol deposition modelling (Gallagher et al., 2002).

\section{Prior assessment and development}

Given the interaction of objectives, it was important to design the GRAMINAE experiment so that certain tasks would not compromise others, to refine sampling methods and to establish that the effects of interest would be detectable. This required both prior modelling of advection effects, plus several prior method developments in preparation for the experiment: continuous REA measurement for $\mathrm{NH}_{3}$, foliar $\mathrm{N}$ bioassays, and measurement of vertical acid gases and aerosol concentration profiles.

\subsection{Prior modelling of advection effects}

The field site at FAL Braunschweig was initially selected because of the good local infrastructure, control of field management, large field size and presence of a nearby farm $\mathrm{NH}_{3}$ source. Before confirming the exact location of the measurements, it was necessary to show that advection effects would be significant, but not so large as to dominate the flux and uncertainties, which would prevent assessment of other interactions.

Based on housed animal numbers (120 cows, 130 other cattle, 100 pigs), $\mathrm{NH}_{3}$ emissions from the farm unit were estimated using standard emissions factors to be $10.1 \mathrm{~kg}$ $\mathrm{NH}_{3}$ day $^{-1}$. The possible measurement locations in the main grass field ("Kleinkamp") (see Sect. 4.1) were $\sim 400-800 \mathrm{~m}$ east of the farm unit, allowing for sufficient fetch in the field under westerly air flow. The MODDAS model (Loubet et al., 2006) was applied to estimate the horizontal gradients in $\mathrm{NH}_{3}$ concentrations and the advection errors in vertical $\mathrm{NH}_{3}$ fluxes $\left(F_{z(a d)}\right)$ with distance from the farm source 

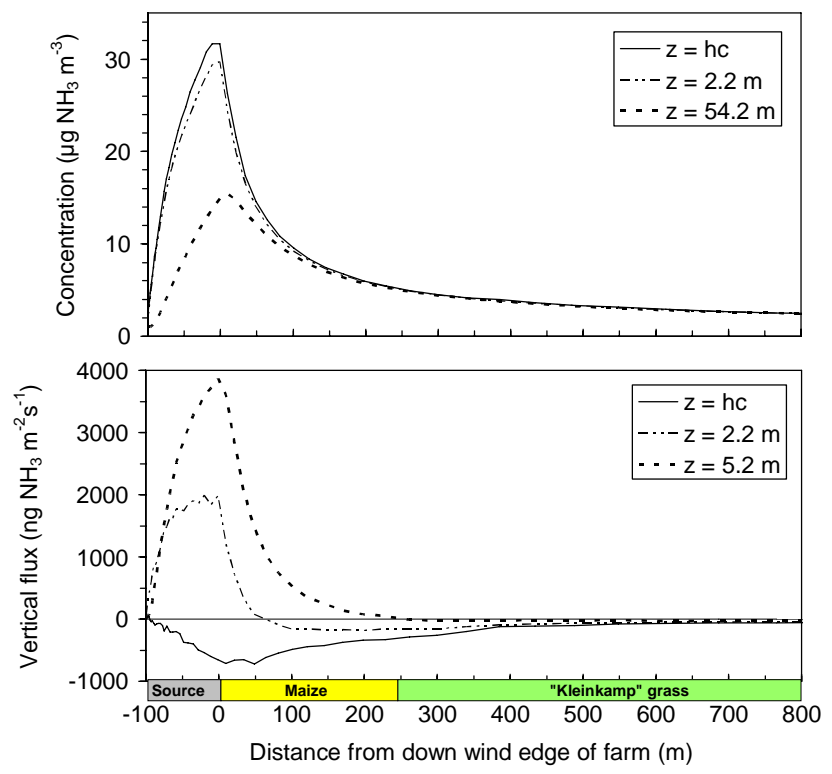

Fig. 1. Prior modelling of the effect of upwind farm $\mathrm{NH}_{3}$ emissions on $\mathrm{NH}_{3}$ concentrations and total vertical fluxes. Advection errors in the vertical flux represent the difference in the vertical flux between canopy height ( $\mathrm{h}_{c}=1 \mathrm{~m}$ above ground) and specified heights above ground. Advection errors are substantial in the first 100-200 $\mathrm{m}$ from the source, but decrease to values smaller than typical $\mathrm{NH}_{3}$ fluxes (50-100 $\mathrm{ng} \mathrm{m}^{-2} \mathrm{~s}^{-1}$ ) at distances larger than $400 \mathrm{~m}$ from the farm. Results of the MODDAS model (Loubet et al., 2006) using a farm source height of $1-4 \mathrm{~m}$, windspeed $(10 \mathrm{~m})$ of $4.5 \mathrm{~m} \mathrm{~s}^{-1}$, and background $\mathrm{NH}_{3}$ of $1 \mu \mathrm{g} \mathrm{m}^{-3}$.

(Figs. 1, 2). The modelled concentrations were found to be in reasonable agreement with preliminary measurements of $\mathrm{NH}_{3}$ concentrations (October-November 1999). Monthly mean $\mathrm{NH}_{3}$ values at different locations around the farm (see Sect. 4.1) ranged $12-33 \mu \mathrm{g} \mathrm{m}^{-3}$, while at $240 \mathrm{~m}$ east of the farm the measured mean concentration was $3.5 \mu \mathrm{g} \mathrm{m}^{-3}$ compared with a background of $2.2 \mu \mathrm{g} \mathrm{m}^{-3}$.

The model analysis showed that advection errors would dominate $\mathrm{NH}_{3}$ fluxes at distances closer than $\sim 100 \mathrm{~m}$ from the farm $\left(F_{z(\operatorname{adv}, 2.7 \mathrm{rmm}-h c)}>400 \mathrm{ng} \mathrm{m}^{-2} \mathrm{~s}^{-1}\right)$, with the increased values of $F_{z(a d v)}$ for larger measurement heights. By contrast, at the furthest measurement distance $(780 \mathrm{~m}) \mathrm{calcu}-$ lated values of $F_{z(\operatorname{adv}, 2.7 \mathrm{~m}-h c)}$ were $\sim 20 \mathrm{ng} \mathrm{m}^{-2} \mathrm{~s}^{-1}$, while the value for $550 \mathrm{~m}$ was $28 \mathrm{ng} \mathrm{m}^{-2} \mathrm{~s}^{-1}$ (for periods when the measurement sites would be downwind of the farm source). The values at these larger distances are small enough not to be important in periods of high $\mathrm{NH}_{3}$ emission (e.g., after fertilization), but would be significant for periods of smaller $\mathrm{NH}_{3}$ fluxes (e.g., prior to cutting). This analysis supported the use of the FAL Braunschweig field, and it was concluded to use two distances for flux measurement $(550 \mathrm{~m}, 780 \mathrm{~m}$, Fig. 3), supported by measurement of $\mathrm{NH}_{3}$ concentrations closer to the farm.

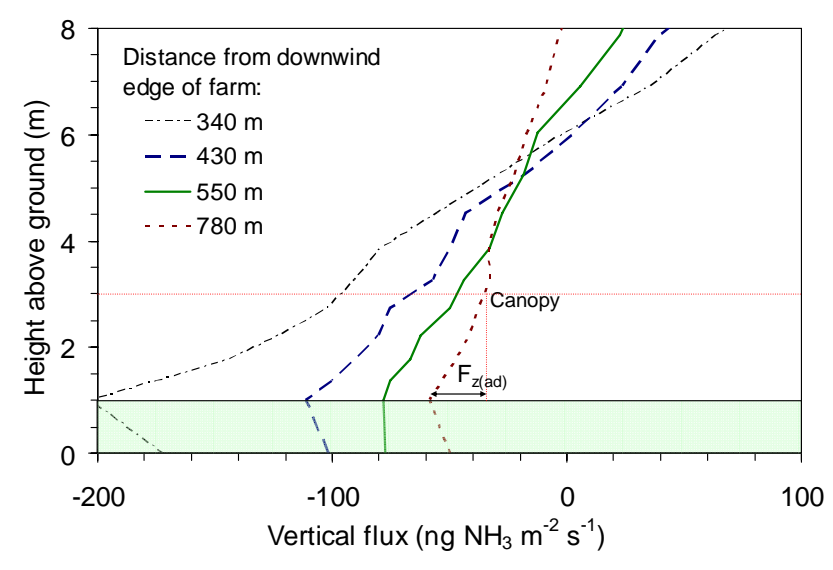

Fig. 2. Prior modelling of the potential effect of upwind farm $\mathrm{NH}_{3}$ emissions on changes in the vertical flux with height using the MODDAS model. Model values are as specified for Fig. 1. The horizontal arrow shows the divergence in the vertical flux (the advection error, $\left.F_{z(a d)}\right)$ between a flux measurement made at $3 \mathrm{~m}$ above ground and the flux at the canopy surface ( $1 \mathrm{~m}$ above ground) for an example where fluxes are measured $780 \mathrm{~m}$ from the downwind edge of the farm.

3.2 Development of relaxed eddy accumulation systems for ammonia

Continuous systems to measure vertical concentration gradients have largely used wet chemical methods and have become widely available (Wyers et al., 1993; Sutton et al., 1995b, 2007; Neftel et al., 1998). By contrast, although traditional batch sampling techniques have been applied to measure $\mathrm{NH}_{3}$ fluxes by REA (Zhu et al., 2000), continuous REA systems for $\mathrm{NH}_{3}$ represent an ongoing challenge. A significant effort was therefore invested in GRAMINAE to refine and test several continuous implementations for REA (e.g., Neftel et al., 1999; Erisman et al., 2001b; Sutton et al., 2001a; Nemitz et al., 2001a, Pryor et al., 2002), which were then compared in the GRAMINAE experiment.

\subsection{Development of bioassays of ammonia emission poten- tial}

It is well known that "compensation point" concentrations apply to $\mathrm{NH}_{3}$ exchange with vegetation, these being the air concentrations of $\mathrm{NH}_{3}$ at which no net flux occurs, with component emission fluxes balancing uptake at different scales (e.g. Farquhar et al., 1980; Sutton et al. 1995b). The stomatal compensation point $\left(\chi_{s}\right)$ represents the air concentration in equilibrium with the apoplastic (intercellular) fluids of plant leaves. The temperature dependent value of $\chi_{s}$ can be calculated from the thermodynamic equilibria and the ratio the ratio $\left[\mathrm{NH}_{4}^{+}\right] /\left[\mathrm{H}^{+}\right]$in the apoplast, denoted $\Gamma_{s}$ (Sutton et al., 2000b; Nemitz et al., 2000b, 2001b), making it of great interest to refine bioassays for determination of $\left[\mathrm{NH}_{4}^{+}\right]$and 


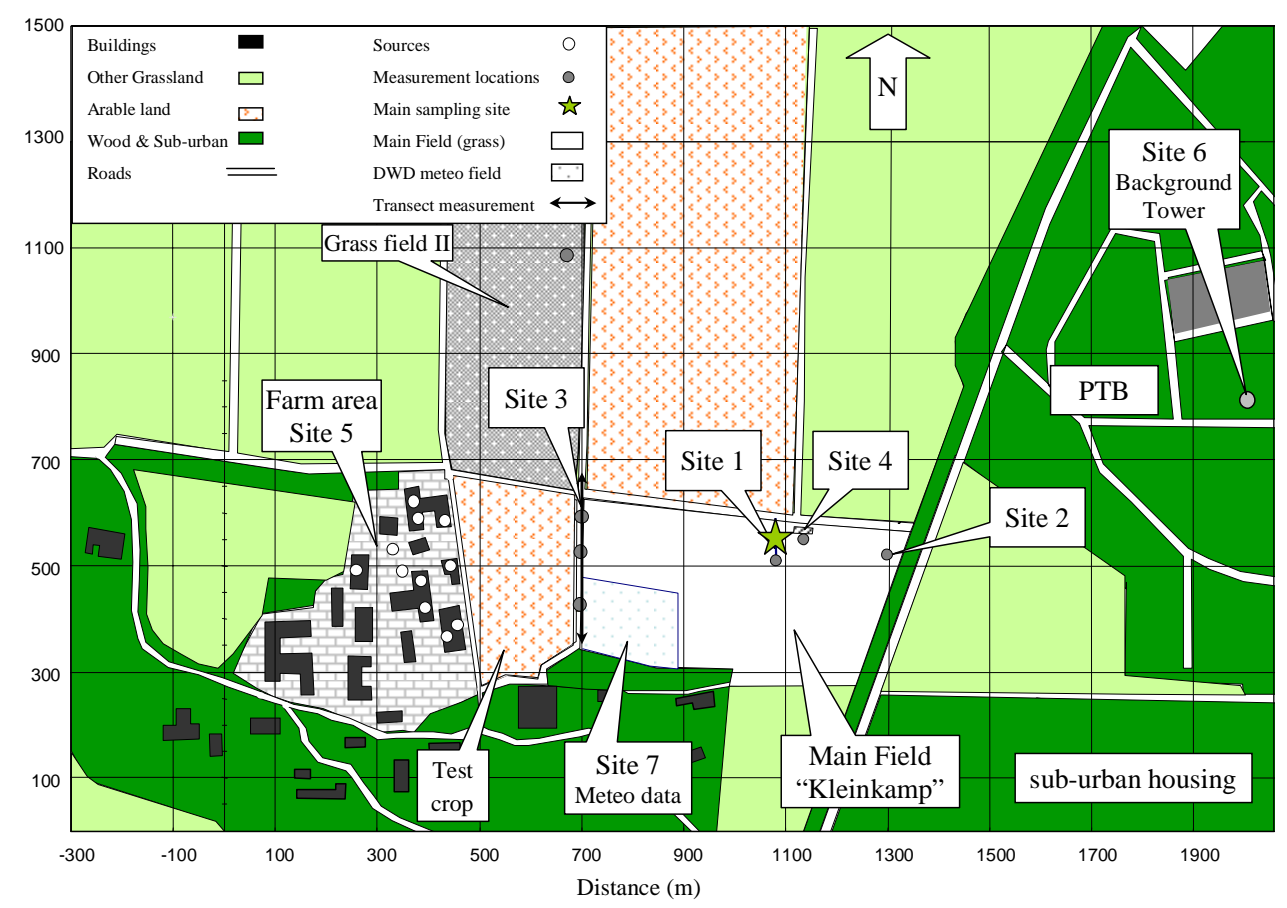

Fig. 3. Site map of the GRAMINAE Braunschweig Experiment on the site of the FAL. Sites: 1, Main micrometeorological flux measurement site; 2, Micrometeorological $\mathrm{NH}_{3}$ flux measurement at increased distance from the farm; $3, \mathrm{~N}-\mathrm{S}$ transect for mobile $\mathrm{NH}_{3}$ plume measurements including three fixed points; 4, Small plots (each $10 \mathrm{~m} \times 10 \mathrm{~m}$ ) for comparison of grass management options; 5, FAL farm buildings; 6, Tower of the PTB for measurement of background air at $43 \mathrm{~m}$ above ground; 7, Meteorological measurement site of the Deutscher Wetter Dienst. Axes in metres.

$\left[\mathrm{H}^{+}\right]$. A critical experimental evaluation of such methods was therefore made (Husted et al., 2000b), including analysis of practical issues such as the extent of $\mathrm{pH}$ buffering on extracted (diluted) apoplastic solutions (Hill et al., 2001).

Prior development of an ecosystem model of coupled grassland $\mathrm{C}-\mathrm{N}$ cycling and $\mathrm{NH}_{3}$ exchange (Sutton et al., 2001a; Riedo et al., 2002) also highlighted the importance of different plant $\mathrm{N}$ pools, including "substrate nitrogen" being the nitrogen available for plant growth, as compared to that built into plant structures. Although this term represents a model construct, efforts were made in preparation for the GRAMINAE Experiment to develop a measurement of total soluble nitrogen concentrations in the plant as an estimate of substrate nitrogen, to complement other indicators, such as total foliar ammonium and nitrate (Husted et al., 2000a, b; Loubet et al., 2002; Mattsson and Schjoerring, 2003).

\subsection{Measurement of ammonia interactions with particles}

Several fast response optical methods were already available for the measurement of particle fluxes, by EC, including condensation particle counters (CPC) and Active Scattering Aerosol Spectrometer Probes (ASASP-x) (e.g., Gallagher et al., 1997; Nemitz et al., 2002, 2004b). A key challenge, however is the continuous measurement of chemically speciated aerosol fluxes. For this purpose the steam jet aerosol col- lector (SJAC) approach (Khlystov et al., 1995) coupled with a denuder system for acid gases, running with on-line chromatography is well suited (Jongejan et al., 1997; Wolff et al., 2007). In preparation for the GRAMINAE experiment, development efforts focused on building a full dual channel system (cf. Nemitz et al., 2004b), permitting measurement at two heights simultaneously, which allowed fluxes to be calculated using the AGM.

\section{$4 \quad$ Field site and measurement strategy}

\subsection{Description of the field site}

The site at FAL is located at latitude $52^{\circ} 18^{\prime} \mathrm{N}$ and longitude $10^{\circ} 26^{\prime} \mathrm{E}$, being rather flat at $79 \mathrm{~m}$ above mean sea level. FAL is situated at the fringe of the Lower Saxonian city of Braunschweig (Brunswick) with 245000 inhabitants, $12 \mathrm{~km} \mathrm{WNW}$ of the city centre. It is therefore subject to mixed agricultural air masses for SW to $\mathrm{N}$ wind directions and more urban air masses for easterly winds. The main field of the experiment, "Kleinkamp" (Fig. 3), is surrounded by arable and other managed grassland to the $\mathrm{N}$, woodland, by grassland and sub-urban development to the $\mathrm{E}$ and $\mathrm{S}$, and by experimental arable plots and the FAL farm to the west. 
The FAL Farm is the main $\mathrm{NH}_{3}$ point source in the immediate locality, which typically houses (according to the prior estimates) 120 dairy cows, 130 other cattle and 100 pigs (50 being in a house fitted with $\mathrm{NH}_{3}$ scrubbing technology). Based on emission factors for housing and manure storage, $92 \%$ of the $\mathrm{NH}_{3}$ emission was estimated to result from cattle excreta. A further source of $\mathrm{NH}_{3}$ was liquid cattle manure (slurry) spreading on Field II (see Fig. 3) at 17:00 GMT 22 May, leading to $\mathrm{NH}_{3}$ plumes over Kleinkamp during spreading and at $\sim 18: 0024$ May. Emissions from this source ceased on 25 May, following irrigation with dirty water.

The Kleinkamp field (12 ha) has a sandy soil, with an upper rooting and ploughing A horizon with a high organic matter content, a yellow $\mathrm{C} 1$ horizon with occasional worm and root penetration, and below this a red coloured $\mathrm{C} 2$ horizon, including $\sim 20 \%$ gravel and flints. Following FAO nomenclature, the soil is a dystric-luvic-cambisol on silty-sandy, cover-sediments overlying gravelly-sandy moranic deposits and glacifluviatile sands. Further details are given in Table 1.

The field was sown in March 1996 with $55 \mathrm{~kg} \mathrm{ha}^{-1}$ "Country 2010" seed: Lolium perenne (6 varieties, $29 \%$ by mass), Festuca pratensis (2 vars., 33\%), Poa pratensis (2 vars., 12\%), Phleum pratense (4 vars., 18\%) Festuca rubra (3\%) and Trifolium repens (5\%). A further $20 \mathrm{~kg} \mathrm{ha}^{-1}$ Lolium perenne was intersown on 20 March 2000.

From 1996 to 1999, the field typically received 1 application of liquid animal manure (slurry) each spring (between 25 January and 20 March) at 30-50 tonne ha ${ }^{-1}$ with an estimated $\mathrm{N}$ content of $1 \mathrm{~kg} \mathrm{~N}$ tonne ${ }^{-1}$. Annually, the field received 2-4 applications of mineral fertilizer between March and September (usually urea - ammonium nitrate solution). Overall, the field received annual mineral fertilizer inputs of 144, 220, 212 and $288 \mathrm{~kg} \mathrm{~N} \mathrm{ha}^{-1}$ for the years 1996, 1997, 1998 and 1999, respectively, with an additional average slurry input of $37.5 \mathrm{~kg} \mathrm{Nha}^{-1}$ year $^{-1}$. In order to simplify conditions for the GRAMINAE experiment, no animal manure was applied in 2000 prior to June. Instead only calcium ammonium nitrate was used, with $100 \mathrm{~kg} \mathrm{~N} \mathrm{ha}^{-1}$ being applied on 27 March 2000 and $108 \mathrm{~kg} \mathrm{~N} \mathrm{ha}^{-1}$ being applied on 5 June 2000 (as part of the experiment). The field was ungrazed since sowing, being cut for silage once in June 1996, twice in 1997 (May and June), and three times each in 19981999 (May, June, August). In 2000 the first cut was made on 29 May 2000 (as part of the experiment).

\subsection{Spatial measurement strategy}

Measurements were made at a series of 7 main sites in order to meet the different objectives of the experiment, as shown in Fig. 3. Mains electricity was provided to all sampling sites, with temporary installations established for the experiment at Sites 1-4.
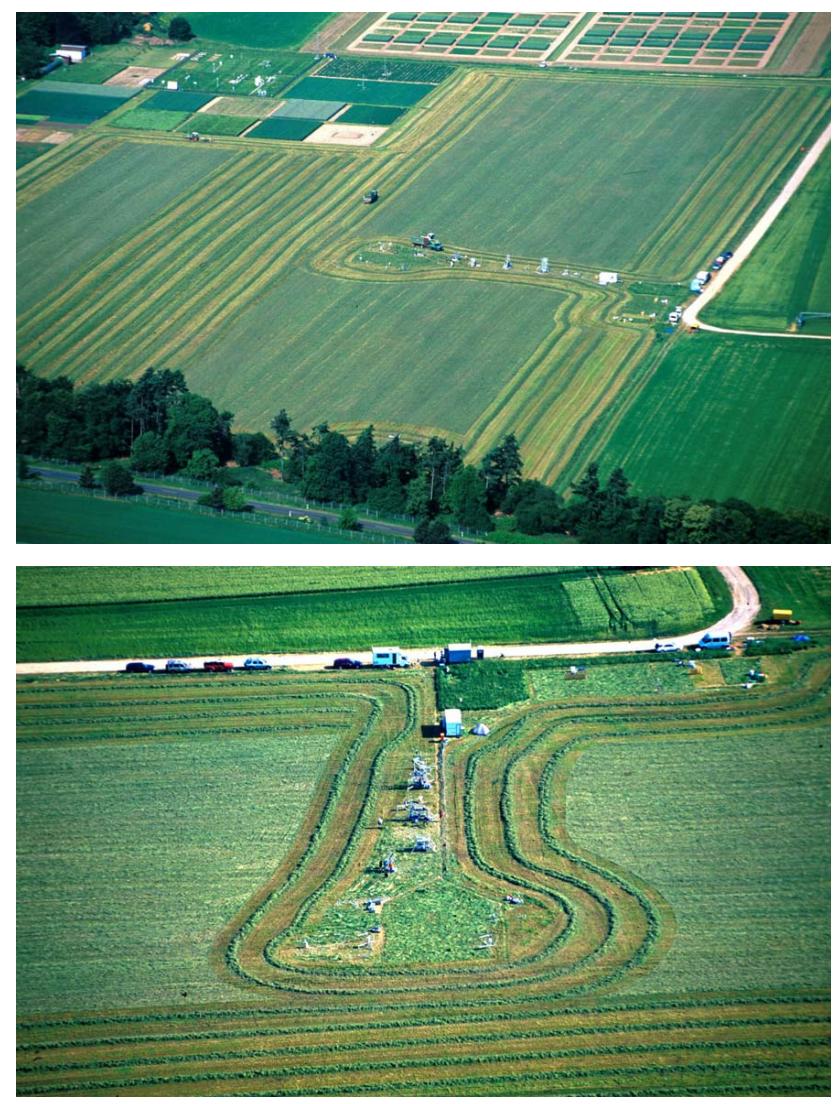

Fig. 4. Aerial photographs of the GRAMINAE Braunschweig Experiment during lifting of the grass, 08:00 GMT 31 May 2000: (a) the main field looking from the ENE with the main field site in the centre and the DWD station in the top left, (b) Close up of Sites 1 and 4 , looking from the $\mathrm{S}$.

\subsubsection{Site 1: Main sampling site}

The main flux measurement site was located at $550 \mathrm{~m}$ east of the FAL farm in the centre of Kleinkamp. This site was selected on the basis of the prior modelling of advection (Sect. 3.1) as being sufficiently far from the farm to have only moderate advection effects in westerly winds, while being generally suitable for flux measurements (fetch over Kleinkamp of $>150 \mathrm{~m}$ ) when winds were from $20-180^{\circ}$ and from $190-360^{\circ}$. The measurements at this site were made in a N-S line 40-80 m from the $\mathrm{N}$ edge, and then with two lines (20 m apart) $90-110 \mathrm{~m}$ from the $\mathrm{N}$ edge of the field (see Figs. 4 and 5). The field measurements at Site 1 were supported by two mobile laboratories (Fig. 4b) for deployment of particle-sampling equipment (UoM Lab., $30 \mathrm{~m}$ into the field) and for chemical preparation (ECN Mobile Lab., at the $\mathrm{N}$ edge of the field). Details of the measurements made are given in Sect. 5. 
Table 1. Soil conditions the main study field of the GRAMINAE integrated experiment ("Kleinkamp”).

\begin{tabular}{|c|c|c|c|}
\hline & Horizon A & Horizon $\mathrm{C} 1$ & Horizon $\mathrm{C} 2$ \\
\hline Horizon depth $(\mathrm{cm})^{\mathrm{a}}$ & $0-27$ & $27-71$ & $71-80$ \\
\hline Bulk soil density (g dry soil $\left.\mathrm{cm}^{-3}\right)^{a}$ & 1.73 & 1.61 & 1.58 \\
\hline Clay/Silt/Sand fraction $(\%)^{\mathrm{a}}$ & $3 / 34 / 63$ & $3 / 31 / 66$ & - \\
\hline Volumetric saturated water content $(\%)^{\mathrm{a}}$ & 37.1 & 42.2 & 45.6 \\
\hline Volumetric water content at field capacity $\mathrm{pF} 2(\%)^{\mathrm{a}}$ & 21.90 & 16.70 & 19.30 \\
\hline Saturated hydraulic conductivity $\left(\mathrm{mm} \mathrm{d}^{-1}\right)^{\mathrm{a}}$ & 47.0 & 382 & 586 \\
\hline Cation Exchange Capacity (mgee/100 g soil) ${ }^{\mathrm{a}}$ & 6.85 & 3.94 & 6.78 \\
\hline Soil Organic Carbon $\left(\mathrm{g} \mathrm{C} \mathrm{kg}^{-1}\right)^{\mathrm{b}, \mathrm{c}}$ & $21.2 / 8.9$ & 3.9 & - \\
\hline Soil Organic Nitrogen $\left(\mathrm{g} \mathrm{N} \mathrm{kg}^{-1}\right)^{\mathrm{b}, \mathrm{c}}$ & $1.56 / 0.60$ & 0.22 & - \\
\hline Soil pH (in $\left.0.01 \mathrm{M} \mathrm{CaCl}_{2}\right)^{\mathrm{b}}$ & $6.35 / 6.85$ & - & - \\
\hline
\end{tabular}

${ }^{\text {a }}$ Sampled on 5 June $2000 .{ }^{b}$ Using soil layers 0-10/10-30 \& 30-60 cm, where available. ${ }^{c}$ From a full analysis in 1984.

\subsubsection{Site 2: Far field site}

Site 2 was located at $750 \mathrm{~m}$ east of the farm, approximately $25 \mathrm{~m}$ from the $\mathrm{E}$ edge of Kleinkamp. It was established to permit independent measurement of ammonia fluxes at a site with smaller advection errors than Site 1, due to the larger distance from the FAL farm. A gradient AMANDA system (Wyers et al., 1993) was deployed allowing fluxes to be measured by the AGM, together with measurement of turbulence and sensible heat fluxes by an ultra-sonic anemometer using EC. Fetch was $>150 \mathrm{~m}$ for the sector $200-290^{\circ}$.

\subsubsection{Site 3: Near-farm transect}

A N-S transect was used to measure plumes of $\mathrm{NH}_{3} 200$ $250 \mathrm{~m}$ downwind of the FAL farm under westerly flow. At this site, a mobile, fast-response $\mathrm{NH}_{3}$ analyzer was deployed for transect measurements, together with 3 single-channel AMANDA analyzers fixed at 50, 150 and $250 \mathrm{~m}$ from the $\mathrm{N}$ edge of the field (Hensen et al., 2009).

\subsubsection{Site 4: Small plots}

In order to address the effect of different management options on net ammonia exchange (Sect. 4.3), 4 small plots, each of $\sim 10 \mathrm{~m} \times 10 \mathrm{~m}$, were marked out from the Kleinkamp field at the start of the experiment. These plots were located at the $\mathrm{N}$ edge of the field, NE of Site 1 (Figs. 3 and 4). The main field was designated as Plot 1 (periods A and B), with the small plots designated as Plots A2, A3, B2, B3. In addition, a further $15 \mathrm{~m} \times 20 \mathrm{~m}$ was left uncut and unfertilized (Plot C) for determination of vertical profiles of turbulence, temperature and $\mathrm{NH}_{3}$ within the canopy after the cut $(\mathrm{Ne}$ mitz et al., 2009c). Measurements in the small plots focused on cuvette measurements of $\mathrm{NH}_{3}$ fluxes (David et al., 2009a, b) and foliar $\mathrm{N}$ bioassays in relation to altered soil, vegetation and microclimate (Mattsson et al., 2009a) Site 4 was supported by two further mobile laboratories (Fig. 4b) for apoplastic extractions and plant handling (UoC/FAL-D Lab) and for measurements related to the small plots (INRA Lab).

\subsubsection{Site 5: FAL Farm buildings}

A record was kept of the numbers of different types of livestock in each of the farm buildings during the experiment, allowing detailed calculation of $\mathrm{NH}_{3}$ emissions according to the inventory approach (Hensen et al., 2009). The sources included both livestock houses and manure stores and the location of the main sources is shown on Fig. 3. Ammonia concentrations were measured at several points around the farm using passive samplers, according to the method of Ferm and Rodhe (1997).

\subsubsection{Site 6: Tall tower background site}

In order to study the effect of surface perturbation of $\mathrm{NH}_{3}$, $\mathrm{HNO}_{3}, \mathrm{HCl}$ and aerosol equilibria, it was desirable to obtain measurements of gas concentrations in the well mixed atmosphere, well above the surface. For this purpose, a tower building of the German National Metrology Institute (Physikalisch Technische Bundanstalt, PTB) $1 \mathrm{~km}$ ENE of Site 1 provided a measuring platform $43 \mathrm{~m}$ above ground. An automatic batch wet-denuder (Keuken et al., 1988) was deployed for hourly measurement of $\mathrm{NH}_{3}, \mathrm{HNO}_{3}, \mathrm{HCl}$ and $\mathrm{SO}_{2}$ for key periods during the experiment.

\subsubsection{Site 7: Permanent meteorological measurement site}

The Kleinkamp field is immediately adjacent to a centre of the Deutscher Wetter Dienst (DWD), which makes permanent meteorological and agro-meteorological measurements over several canopy types. The main DWD site is $\sim 250 \mathrm{~m} \mathrm{E}$ of the farm, while windspeed and direction (used for the local dispersion modelling, Loubet et al., 2009) were measured $(10 \mathrm{~m})$ at the NE corner of the "test crop" shown on Fig. 3. 


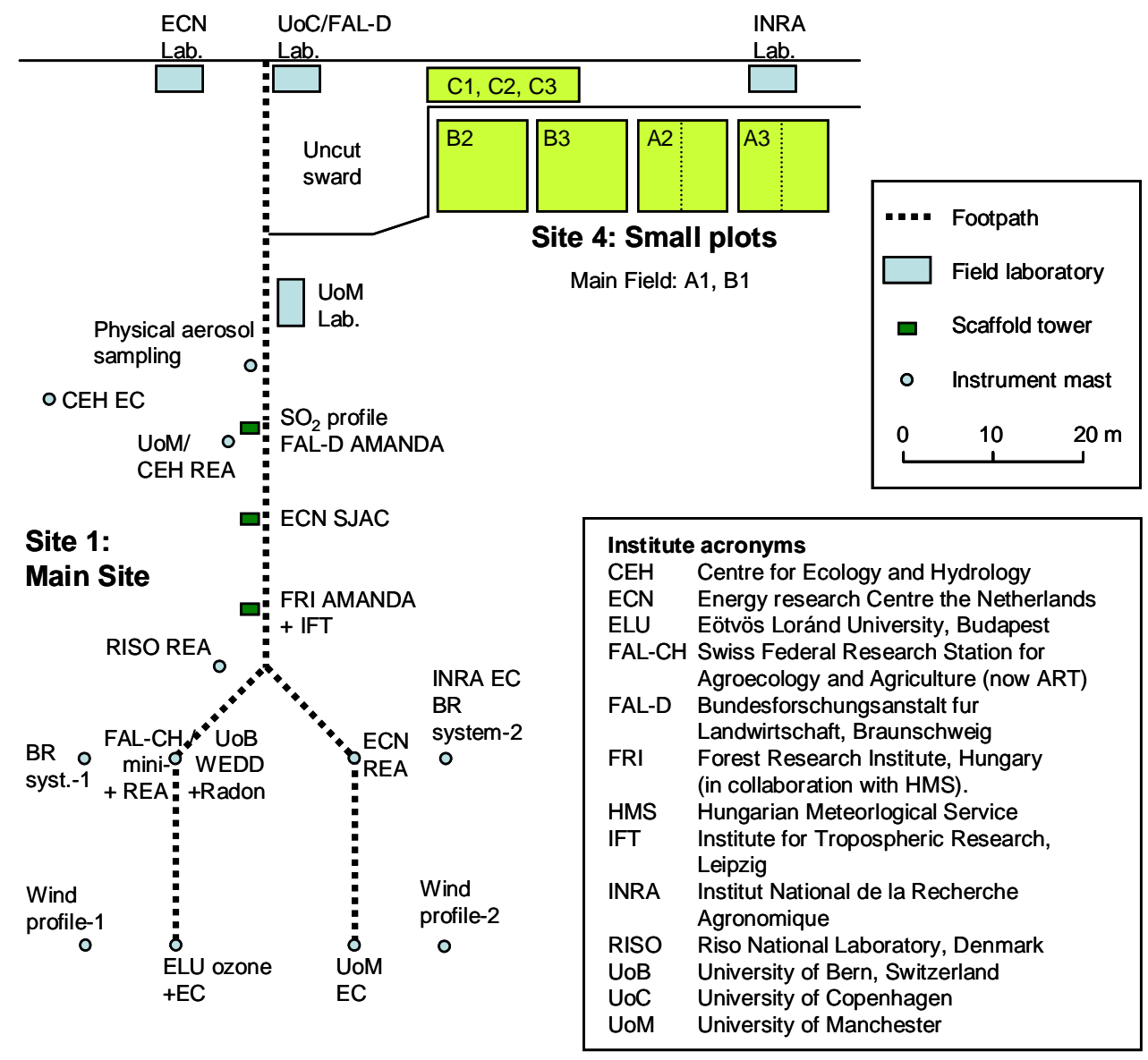

Fig. 5. Detailed plan of Sites 1 and 4. Notes: EC, eddy covariance system; BR, Campbell Scientific Bowen Ratio System; REA, Relaxed Eddy Accumulation system for ammonia; SJAC, gradient Steam Jet Aerosol Collector system; AMANDA, gradient continuous $\mathrm{NH}_{3}$ wet denuder system; WEDD, wet effluent diffusion denuder system for $\mathrm{NH}_{3}$. Key instrumentation and facilities operated by different institutes are shown.

\subsection{Temporal measurement strategy}

The experiment was divided into three measurement periods of approximately one week to study the effects of cutting and fertilization on ammonia fluxes and exchange processes. The field site was measured out, electricity installed and equipment established on 14-22 May 2000, with measurements started at 12:00 Greenwich Mean Time (GMT) on 22 May. This allowed seven days of measurements before the grass was cut (from $\sim 0.75$ to $0.07 \mathrm{~m}$ height) at 06:00-10:00 GMT on 29 May. On the morning of 30 May, the grass was turnedover using mechanical "spinners' to help dry it and was then lifted from the field 06:00-10:00 GMT on 31 May. Hand raking of the grass around the sampling equipment at Site 1 was complete by 12:00 GMT.

Seven days after cutting, the field was fertilized with nitrogen at 06:00-07:00 on 5 June (Sect. 4.1), allowing the effects of fertilization of the main field to be followed for 10 days, before measurements were stopped at 12:00 GMT on 15 June.

\subsubsection{Measurement strategy on the main field}

Micrometeorological measurements of net $\mathrm{NH}_{3}$ fluxes were made throughout the experiment using the AGM, while additional resources were deployed to address different questions before and after the cut. Before the cut, particular attention was given to measuring within-canopy turbulence and $\mathrm{NH}_{3}$ concentration profiles (Nemitz et al., 2009c) investigating the nature of canopy sources and sinks of $\mathrm{NH}_{3}$. This also included attention to vertical profiles of apoplastic bioassays (Hermann et al., 2009) and differences between plant species (Mattsson et al., 2009b). After the cut, the $\mathrm{NH}_{3}$ detection systems (ECN, FAL-CH) used for within-canopy profiles, were deployed in the intercomparison of REA methods (Hensen et al., 2008), while bioassay measurements focused on measuring the consequences of different management options using the small plots (Sect. 4.4.2) and on determining the extent of diurnal variability of apoplastic $\left[\mathrm{NH}_{4}^{+}\right]$ and $\left[\mathrm{H}^{+}\right]$and total tissue $\mathrm{NH}_{4}^{+}$and $\mathrm{NO}_{3}^{-}$. Diurnal courses 
of 3-hourly bioassay sampling were made on 26-27 May, 45 June and 12-13 June (Herrmann et al., 2009).

\subsubsection{Measurement strategy of the small plots}

Measurements on the small plots and comparison with the main field allowed the effects of hay/silage management, different levels of $\mathrm{N}$ supply, and the longer term effects after cutting to be tested. The following $10 \mathrm{~m} \times 10 \mathrm{~m}$ plots were defined:

Plot A1: Main field not cut,

Plot A2: Cut early on 24 May, subsequent lifting (for silage) and no $\mathrm{N}$ fertilization,

Plot A3: Cut early on 24 May, grass left to dry (as hay) and no $\mathrm{N}$ fertilization;

Plot B1: Main field cut 29 June and fertilized 5 June with $\sim 100 \mathrm{~kg} \mathrm{Nha}^{-1}$,

Plot B2: Cut 30 June (split into two: silage and hay) and no fertilization,

Plot B3: Cut 30 June and fertilized 5 June with $\sim 200 \mathrm{~kg} \mathrm{Nha}^{-1}$.

While cuvette $\mathrm{NH}_{3}$ flux measurements focused sequentially on Plots A1-3 and then Plots B1-3 (David et al., 2009a, b), the bioassay measurements allowed the responses of Plots A2 and A3 to be followed for up to 3 weeks after cutting (Mattsson et al., 2009a). In addition, supplementary plots (C1, C2, C3) were delineated during the experiment with an additional cut on 10 June (with cut grass removed), the following conditions:

Plot C1: Regrowth of grass, no fertilization,

Plot C2: As C1, but bare soil from 12 June,

Plot C3: As C1, but bare soil from 12 June, plus green leaves added to surface.

\subsection{Data acquisition and reporting}

The Integrated Experiment naturally included a very wide range of measurement types, with different acquisition systems being applied by different groups according to data type. Continuous datasets were logged on instrument dataloggers or PC-based systems by each of the research groups. To ensure comparability of the measurements, data were collected and reported according to common standards: a) for continuous measurements, data were collected on a $15 \mathrm{~min}$ basis (or hourly basis, where this was not possible), b) stated sample times refer to the end-time of the sampling period (i.e., 1230 would denote 1215-1230); c) all measurements were recorded according to GMT (being the Universal Time Constant), which equated to local time minus $2 \mathrm{~h}$. The consolidated datasets were provided as a $\mathrm{CD}$ and on a shared file server to participants (Sutton et al., 2001b).

\subsection{Quality assurance and quality control}

Many of the measurements made during the experiment are known to be very challenging, especially for continuous determination (e.g., $\mathrm{NH}_{3}, \mathrm{HNO}_{3}, \mathrm{NH}_{4}^{+}$and anion aerosols, apoplastic bioassays etc.) and when considering fluxes and gradients rather than just concentrations. In addition to following good experimental practice, the availability of different scientists on-site allowed for regular trouble-shooting and repair of instruments. A key QA element was the use of replicated measurement of the same parameter by different groups using either the same or similar sampling methods. Thus the determination of turbulent exchange parameters (Nemitz et al., 2009b) was made using 9 different ultrasonic anemometers, as well as wind/temperature profiles etc. Similarly, the AGM for $\mathrm{NH}_{3}$ fluxes was applied using 4 independent $\mathrm{NH}_{3}$ detectors (Milford et al., 2008), while assessment of $\mathrm{NH}_{3}$ fluxes by REA also used 4 independent $\mathrm{NH}_{3}$ detectors (Hensen et al., 2008). The continuous measurements of trace gas and aerosol concentrations were also supported by FAL permanent daily denuder/filterpack measurements (300 m N of Site 3). Such inter-comparisons enabled screening of the datasets for outliers, while standard filters were applied for flux calculations (e.g., low windspeed, atmospheric stability and flux footprint, Nemitz et al., 2009b).

Gas-phase calibrations were used for $\mathrm{CO}_{2}$ and $\mathrm{SO}_{2}$ measurements. However, such calibration is uncertain for $\mathrm{NH}_{3}$, and in this case liquid phase calibration of the chemical detectors used was applied, using common aqueous standards for all groups. At three times during the experiment, "mystery solutions" were provided blind to test the performance of the different analysis systems for aqueous $\mathrm{NH}_{4}^{+}$.

\subsection{Summary of measurement methods applied}

As noted above, a large number of sampling systems were applied by the different groups. These are summarized in Table 2, which also notes where the methods are described in more detail. Overall, 14 continuous $\mathrm{NH}_{3}$ measurement systems with online chemical analysis and 2 automatic batch systems were applied during the experiment, relating to 9 different methods/implementations. Four optical measurement systems were used for aerosol physical properties and number concentrations/fluxes, plus two chemical methods. Ten systems (inc. EC, AGM and energy balance methods) were compared for calculation of sensible heat flux, of which four also provided assessment of latent heat fluxes.

Within-canopy micrometeorological measurements included the application of a micro-ultra sonic anemometer and its comparison with a ${ }^{222}$ Radon tracer method to estimate within-canopy turbulence and exchange coefficients (Nemitz et al., 2009c). A wide range of other surface parameters were measured including temperature profiles, leaf temperatures (by attached sensors as well as infra-red detection), 
soil temperatures and leaf wetness, using leaf surface conductivity (Burkhardt and Eiden, 1994).

Soil moisture was sampled continuously using TDR (Time Domain Reflectometry), as well as a theta capacitance probe and by regular gravimetric measurements, focusing on the A horizon at $0-10 \mathrm{~cm}$ and $10-30 \mathrm{~cm}$. Finally, plant material was sampled for $\mathrm{N}$ bioassays being prepared and extracted on-site (UoC lab), including pressure impregnation and extraction of apoplastic extracts using a cooled centrifuge $\left(4^{\circ} \mathrm{C}\right)$ and measurement of apoplastic pH (Mattsson et al., 2009a). Leaf extracts for analysis of $\mathrm{NH}_{4}^{+}$and other $\mathrm{N}$ components were frozen in liquid nitrogen and subsequently stored on site at $-18^{\circ} \mathrm{C}$.

\section{Conditions before and during the experiment}

\subsection{Synoptic meteorology during the experiment}

The meteorology was characterized by mainly $\mathrm{W}$ flow, plus shorter periods of S and SE flow, with several frontal systems passing during the experiment. The NOAA HYSPLIT model was used to calculate daily 24-h back-trajectories for air masses arriving at 12:00 and 00:00 GMT (Czik et al., 2000) and a daily summary has been tabulated by Sutton et al. (2008). Changing conditions on 22 May were followed by W flow on 23-27 May. Surface air masses $(50 \mathrm{~m}$ height on arrival) on 23-27 May were estimated to originate over NW Germany while higher air masses $(1000,1500 \mathrm{~m}$ on arrival) originated from S England and NW France. Warm fronts passed on 23 and 26 of May, followed by a cold front on 27 May.

Following a brief period of S flow on 28 May, W flow resumed on 29-30 May with surface air masses (50 m) originating 24 hours previously over the Benelux countries, while higher air masses originating over $\mathrm{N}$ England. A further period of change on 31 May, was followed by 5 days (1-4 June) of SW flow, with surface air originating $24 \mathrm{~h}$ previously over Germany and higher air masses originating over N France. Warm fronts passed on 1 and 3 June.

The flow changed on 5 June associated with a cold front, to be followed by WNW flow on 6-8 June from over the Netherlands, with higher air masses originating 24 previously over the North Sea. For air masses arriving on 910 June, the flow was from the SE over the Czech Republic and S Germany, with a cold front and associated rain on 10 June. Finally, following change on 11 June, W flow was resumed for 12-15 June, with variable 24 hour backtrajectory origins of surface $(50 \mathrm{~m})$ air being over NW Germany, while higher air masses $(1000,1500 \mathrm{~m})$ originated from the S North Sea and S England.
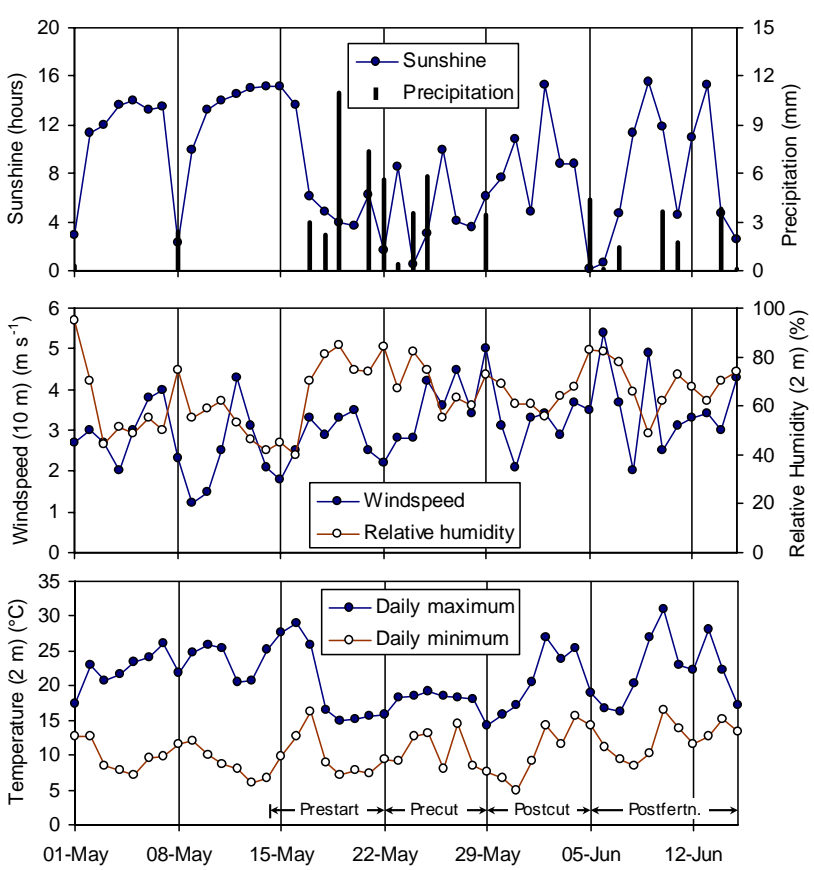

Fig. 6. Daily time course of environmental conditions immediately before and during the measurement period (22 May-15 June) of the GRAMINAE Integrated Experiment. Maxima and minima were calculated from time series of hourly means. The experimental setup period and the three main periods of the experiment are shown (pre-cut, post-cut and post-fertilization).

5.2 Environmental conditions before and during the experiment

An overview of the environmental conditions prior to and during the experiment is shown in Fig. 6. Before the experiment (2-17 May) the conditions were largely dry and sunny, with maximum air temperature ( $2 \mathrm{~m}$, DWD data) between $20-30^{\circ} \mathrm{C}$. These conditions resulted in the farmer irrigating Kleinkamp on 15-17 May, before the experiment started. Conditions were more mixed during the experiment, with in excess of $5 \mathrm{~mm}$ precipitation on 7 days, and maximum temperatures ranging from $14^{\circ} \mathrm{C}$ on 29 May to $31^{\circ} \mathrm{C}$ on 10 June. Mean daily windspeeds during the experiment ranged 2.0 $5.4 \mathrm{~m} \mathrm{~s}^{-1}$ (overall mean $3.4 \mathrm{~m} \mathrm{~s}^{-1}$ ), with mean daily relative humidity in the range $49-83 \%$.

The hourly structure of global radiation, wind direction $(10 \mathrm{~m})$, friction velocity $\left(u_{*}\right)$ and air/canopy temperatures are shown in Fig. 7. The main features of the local wind direction are in accord with the larger scale meteorological flow, including the periods of change on 22 and 31 May, although there was a larger occurrence of surface $E$ winds, such as on 3 and 5 June. This may be related to substantial shear in the atmospheric flow, as identified by the back-trajectory calculations. The most turbulent conditions occurred prior to the cut, associated with cool day-time temperatures. The highest 

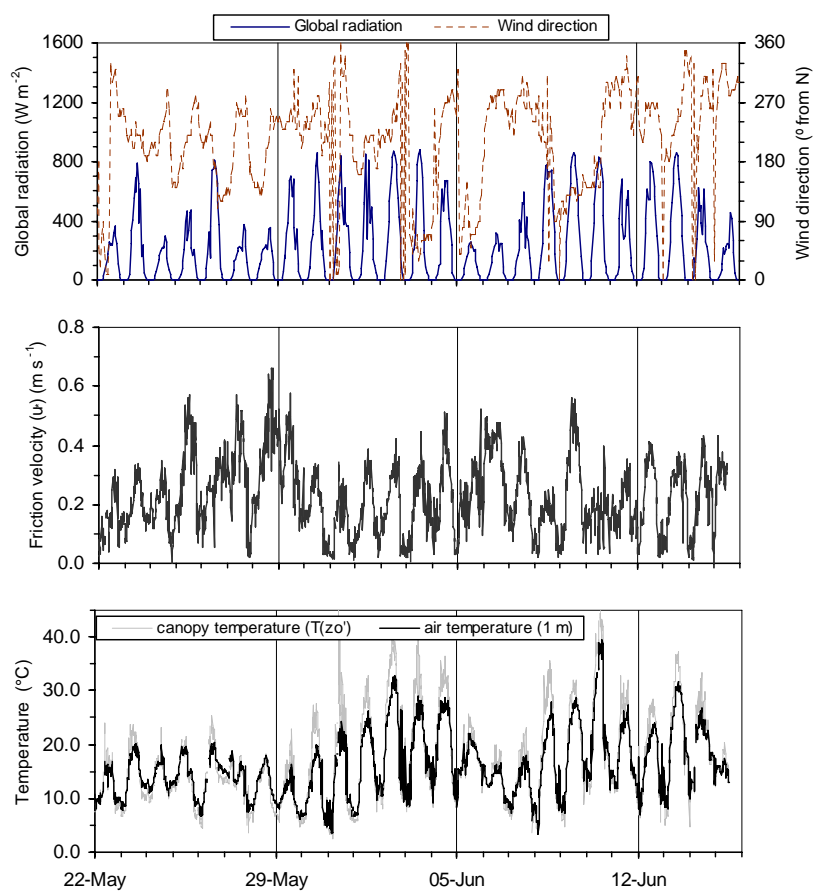

Fig. 7. Structure of wind direction $(10 \mathrm{~m})$, global radiation, friction velocity, air temperature and canopy temperature (micrometeorological estimates at $z_{o}$ ', Nemitz et al., 2009b) during the experiment. The vertical bars every seven days highlight the three main periods of the experiment, with cutting and fertilization on the morning of 29 May and 5 June, respectively.

canopy temperatures occurred on 1-4 and 10 June, with values being larger after cutting due to lower transpiration fluxes (Nemitz et al., 2009b).

\subsection{Air chemistry during the experiment}

The different air-mass origins and local meteorological and environmental conditions provided a wide range of air chemistry conditions during the experiment. This was of great benefit for the experiment, allowing consideration of interactions of gases and aerosols under situations of both potential aerosol growth and evaporation, as well as of differing leafsurface and biological interactions in the presence of altering amounts of acidic $\left(\mathrm{HNO}_{3}, \mathrm{SO}_{2}\right)$ and basic $\left(\mathrm{NH}_{3}\right)$ gases.

The time course of aerosol and gaseous pollutant concentrations during the experiment is shown in Fig. 8. The three physical measurements of particle number concentrations reflect different particle sizes, with categories presented in Fig. $8 \mathrm{a}$ including the fractions $0.01-3 \mu \mathrm{m}$ (CPC), $0.1-3 \mu \mathrm{m}$ (ASASP-x) and $0.5-2.5 \mu \mathrm{m}$ (APS). Since these are number concentrations, the values are dominated by the smallest particle sizes in each range. Thus, the CPC counts are dominated by the nucleation and Aitken modes, the ASASP-x reading by the smaller accumulation mode particles and the APS concentration by the larger accumulation mode. These differences help interpret the aerosol processes occurring at different times. For example on 5 June, surface air was moving little (Sutton et al., 2008) with regional pollution providing a high correlation between accumulation (APS) and Nucleation/Aitken mode (CPC) aerosol. By contrast, on the 9 June, flow from the SE over S. Germany and the Czech Republic (Table 2) brought $\mathrm{SO}_{2}$ - and $\mathrm{HNO}_{3}$ - rich air masses with a low APS reading over Braunschweig to the site, apparently favouring regional nucleation of new particles. The aerosol appears to age over the 10 June, with higher values in the larger size classes. This interpretation is supported by the results of the Differential Mobility Particle Sizer (DMPS), which recorded particle size spectra throughout the experiment. Following a period of small concentrations on 8 June, a nucleation event occurred at 9 am on 9 June, followed by particle growth (through coagulation and condensation) from $8 \mathrm{~nm}$ at 00:00 9 June to $100 \mathrm{~nm}$ by 12:00 10 June (Fig. 9). The "chimney" or "banana" shape of the event on the threedimensional presentation is consistent with nucleation events observed around the globe (e.g., Kulmala et al., 2004).

The ASASP-x's provided the size categories that are most consistent with the mass concentrations of aerosol recorded by the SJAC (Fig. 8b). Although there is a reasonable correlation with $\mathrm{SO}_{4}^{2-}$ mass concentrations, this makes up only $46 \%$ of the measured inorganic anion aerosol mass on average, with $\mathrm{NO}_{3}^{-}$being the largest component, with the SJAC recording only small concentrations $\left(<1 \mu \mathrm{g} \mathrm{m}^{-3}\right)$ of $\mathrm{Cl}^{-}$and $\mathrm{NO}_{2}^{-}$aerosol. The highest $\mathrm{NO}_{3}^{-}$concentrations were associated with the SE and $\mathrm{S}$ flow on 10 June, with high values also at the start of the experiment 23 May under SW flow, which passed over the industrial Ruhr area of Germany.

These peaks are clearly reflected in the $\mathrm{SO}_{2}$ and $\mathrm{HNO}_{3}$ concentrations (Fig. 8c), which were rather similar, at up to 6-8 $\mu \mathrm{g} \mathrm{m}^{-3}$ on the 23 May, 9 and 10 June, while the latter event was also associated with high $\mathrm{O}_{3}$ mixing ratios of up to 70 ppbv indicating significant photochemical activity. These peaks may be contrasted with cleaner periods (e.g., 5-6 June) with only 0.8 and $0.4 \mu \mathrm{g} \mathrm{m}^{-3} \mathrm{SO}_{2}$ and $\mathrm{HNO}_{3}$, respectively.

The "best estimate" of $\mathrm{NH}_{3}$ from the continuous gradient measurements (Milford et al., 2008) was interpolated to $1 \mathrm{~m}$ above canopy, based on the mean of up to four instruments (Fig. 8c). There was some doubt about the performance of two of the AMANDA denuders on selected days (due to disagreement with the two other systems), and for this reason an "alternative estimate" (Milford et al., 2008) is also shown. The $1 \mathrm{~m} \mathrm{NH}_{3}$ surface air concentrations agree very closely with the background air at $43 \mathrm{~m}$ prior to 29 May, while after 5 June, the $\mathrm{NH}_{3}$ concentrations at $1 \mathrm{~m}$ are much larger. This illustrates how, prior to 29 May, $\mathrm{NH}_{3}$ concentrations at $1 \mathrm{~m}$ were largely controlled by external sources, while the later larger values, especially after the 5 May, are mainly due to $\mathrm{NH}_{3}$ emissions from the field itself. The increased $\mathrm{NH}_{3}$ concentrations following cutting and fertilization thus provide the opportunity to investigate consequent interactions 
Table 2. Summary of measured parameters, sampling methods and sampling location of sampling during the GRAMINAE Integrated Experiment.

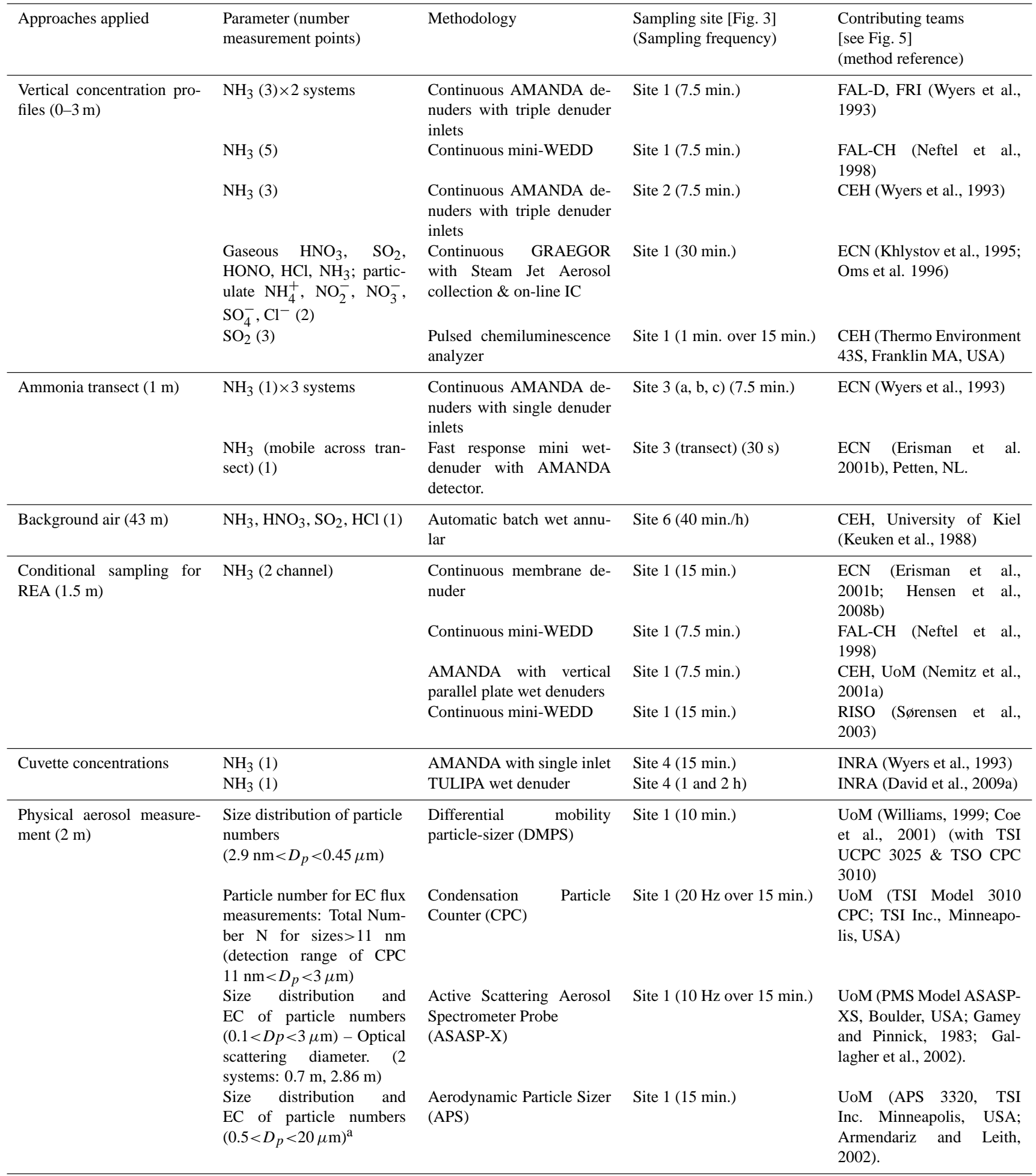

Notes: $D_{p}=$ electrical mobility diameter. ${ }^{\text {a }}$ Time of Flight Aerodynamic Diameter. 
Table 2. Continued.

\begin{tabular}{|c|c|c|c|c|}
\hline Approaches applied & $\begin{array}{l}\text { Parameter (number } \\
\text { measurement points) }\end{array}$ & Methodology & $\begin{array}{l}\text { Sampling site [Fig. 3] } \\
\text { (Sampling frequency) }\end{array}$ & $\begin{array}{l}\text { Contributing teams } \\
\text { [see Fig. 5] } \\
\text { (method reference) }\end{array}$ \\
\hline \multirow[t]{3}{*}{$\begin{array}{l}\text { Other concentration mea- } \\
\text { surements }(2 \mathrm{~m})\end{array}$} & $\begin{array}{l}\text { Size segregated particle } \\
\text { chemistry }\end{array}$ & $\begin{array}{l}\text { Micro-orifice uniform } \\
\text { deposition impactor } \\
\text { (MOUDI) }\end{array}$ & Site 1 (2-3 days) & $\begin{array}{l}\text { CEH (Model 100, MSP } \\
\text { Corp., Minneapolis, USA) }\end{array}$ \\
\hline & $\begin{array}{l}\text { Instantaneous ozone for } \\
\text { eddy covariance }\end{array}$ & $\begin{array}{l}\text { Fast-response fluorescence } \\
\text { detector }\end{array}$ & Site $1(10 \mathrm{~Hz}, 15 \mathrm{~min})$. & $\begin{array}{l}\text { ELU, FRI (NOAA, 1996; } \\
\text { Mészáros et al., 2009) }\end{array}$ \\
\hline & $\begin{array}{l}\mathrm{NO}, \mathrm{NO}_{2}, \mathrm{O}_{3} \text { reference } \\
\text { concentrations }\end{array}$ & Continuous analyzers & Boitzem, $5 \mathrm{~km} \mathrm{~S}$ of FAL & FAL-D \\
\hline \multirow[t]{8}{*}{$\begin{array}{l}\text { Micrometerological } \\
\text { surements }\end{array}$} & $\begin{array}{l}\text { Horizontal wind speed } \\
(5) \times 2 \text { systems }\end{array}$ & Cup anemometers & Site 1 (15 min.) & $\begin{array}{l}\text { CEH \& FRI/ELU (Vector } \\
\text { Instruments, Clywd, UK) }\end{array}$ \\
\hline & $\begin{array}{l}\text { Instantaneous windspeed } \\
(u) \text { and temperature }(T) \\
\text { fluctuations ( } 8 \text { systems) }\end{array}$ & Ultrasonic anemometers & Site 1 (15 min.) & $\begin{array}{l}\text { CEH, INRA, ECN, FAL- } \\
\text { CH, ELU, FRI, UoM (Ne- } \\
\text { mitz et al., 2009b) }\end{array}$ \\
\hline & $\begin{array}{l}\text { Instantaneous } u \text { and } T \text { fluc- } \\
\text { tuations (1 system) }\end{array}$ & Ultrasonic anemometer & Site 2 (15 min.) & CEH (Nemitz et al., 2009b) \\
\hline & $\begin{array}{l}\text { Instantaneous water vapour } \\
(E) \text { fluctuations ( } 2 \text { systems) }\end{array}$ & Krypton hygrometer & Site 1 (15 min.) & $\begin{array}{l}\text { CEH, UoM (KH2O, Camp- } \\
\text { bell Scientific, Loughbor- } \\
\text { ough, UK) }\end{array}$ \\
\hline & $\begin{array}{l}\text { Instantaneous } \mathrm{CO}_{2} \text { and } E \\
\text { (2 systems) }\end{array}$ & Licor 6262 IGRA & Site 1 (15 min.) & CEH, INRA \\
\hline & Mean $E, T$ and air pressure & $\begin{array}{l}\text { Humicap, PRT100 thermis- } \\
\text { tor, Barometric pressure } \\
\text { transducer }\end{array}$ & Site 1 (15 min.) & UoM (Vaisala) \\
\hline & $\begin{array}{l}T \text { and } E \text { profiles }(2 \\
\text { heights), net radiation }(\mathrm{Rn}), \\
\text { total solar radiation }\left(\mathrm{S}_{t}\right), \\
\text { ground heat flux }(\mathrm{G}) \text { and } \\
\text { precipitation (2 systems) }\end{array}$ & $\begin{array}{l}\text { Campbell "Bowen Ratio" } \\
\text { systems (fine thermocou- } \\
\text { ples, dewpoint meter and } \\
\text { additional parameters) }\end{array}$ & Site 1 (15 min.) & $\begin{array}{l}\text { CEH, FRI/ELU (Campbell } \\
\text { Scientific, Loughborough, } \\
\text { UK) }\end{array}$ \\
\hline & $\begin{array}{l}\text { Standard meteo. inc. } \\
u(10 \mathrm{~m}), \mathrm{S}_{t} \text {, direction, } \\
\text { PAR, long-wave radiation, } \\
E, T \text {, precip. etc }\end{array}$ & $\begin{array}{l}\text { Suite of permanent instru- } \\
\text { ments }\end{array}$ & Site 5 (hourly and daily) & Deutscher Wetter Dienst \\
\hline \multirow[t]{8}{*}{$\begin{array}{l}\text { Within canopy mi- } \\
\text { cromet. measurements }\end{array}$} & $\begin{array}{l}\text { Instantaneous } u \text { and } T \text { fluc- } \\
\text { tuations in plant canopy (1 } \\
\text { system) }\end{array}$ & $\begin{array}{l}\text { Kayo Denki micro } \\
\text { ultrasonic- anemometer }\end{array}$ & Site 1 (15 min.) & $\begin{array}{l}\text { CEH (Kayo Denki corp, } \\
\text { Japan; Nemitz et al., 2009c) }\end{array}$ \\
\hline & $\begin{array}{l}\text { Ground wetness (2 sys- } \\
\text { tems) }\end{array}$ & Resistance plate & Site 1 (15 min.) & FRI, Univ. Bonn \\
\hline & $\begin{array}{l}\text { Leaf wetness (4 sampling } \\
\text { points) }\end{array}$ & $\begin{array}{l}\text { RESI (leaf surface resis- } \\
\text { tance) }\end{array}$ & Site 2 (15 min.) & $\begin{array}{l}\text { Univ. Bonn (Burkhardt and } \\
\text { Eiden, } 1994 \text { ) }\end{array}$ \\
\hline & $\begin{array}{l}\text { Rain chemistry and dew } \\
\text { chemistry }\end{array}$ & $\begin{array}{l}\text { Analysis by ion- } \\
\text { chromatography }\end{array}$ & Site 1 (event basis) & FAL-D, UoC, Univ. Bonn \\
\hline & $\begin{array}{l}T \text { profile in canopy and leaf } \\
\mathrm{T} \text { (10 sensors) }\end{array}$ & $\begin{array}{l}\text { Thermocouples, inc. leaf } \\
\text { clips }\end{array}$ & Site 1 (15 min.) & INRA \\
\hline & $\begin{array}{l}\text { Radiative canopy tempera- } \\
\text { ture }\end{array}$ & Infrared temperature sensor & Site 1 (15 min.) & $\begin{array}{l}\text { UoM (KT19 IR pyranome- } \\
\text { ter) }\end{array}$ \\
\hline & $\begin{array}{l}\text { Leaf level water vapour } \\
\text { conductance }\end{array}$ & Leaf cuvette & Site 1 (key periods) & $\mathrm{UoC}$ \\
\hline & $\begin{array}{l}{ }^{220} \text { Radon and }{ }^{222} \text { Radon ( } 3 \\
\text { heights) }\end{array}$ & $22 \times$ Radon analyzer & Site 1 (15 min.) & $\begin{array}{l}\text { UoB, FAL-CH (Lehmann et } \\
\text { al., 1999) }\end{array}$ \\
\hline
\end{tabular}

with the acid gases and aerosols. Not surprisingly, the time course of $\mathrm{NH}_{4}^{+}$aerosol follows that of aerosol anions, and for much of the time (esp. 22-25 May, 4 June, 8-10 June) completely neutralized the equivalent anions (average neutralization $94 \%$ ).

While there were clear relationships of the aerosol concentrations to air mass origin, there was only a weak relationship to local $(10 \mathrm{~m})$ wind direction (Fig. 10) indicating a significant contribution from long-range transport. By con- trast, $\mathrm{NH}_{3}, \mathrm{SO}_{2}$ and $\mathrm{HNO}_{3}$ were largest for $\mathrm{SE}$ winds, with the latter linked to the episode on 8-10 June, indicating pollution of more local/regional origin.

\subsection{Plant and soil conditions during the experiment}

At the time of cutting, the grass was $0.75 \mathrm{~m}$ tall, with a single sided Leaf Area Index (LAI) of 3.06. Cutting reduced the sward to $0.07 \mathrm{~m}$ tall with a LAI of 0.14 . 
Table 2. Continued.

\begin{tabular}{|c|c|c|c|c|}
\hline Approaches applied & $\begin{array}{l}\text { Parameter (number } \\
\text { measurement points) }\end{array}$ & Methodology & $\begin{array}{l}\text { Sampling site [Fig. 3] } \\
\text { (Sampling frequency) }\end{array}$ & $\begin{array}{l}\text { Contributing teams } \\
\text { [see Fig. 5] } \\
\text { (method reference) }\end{array}$ \\
\hline Foliage measurements & $\begin{array}{l}\text { Canopy height meter } \\
\text { Leaf apoplastic concentra- } \\
\text { tions and other foliar } \mathrm{N} \text { pa- } \\
\text { rameters }\end{array}$ & $\begin{array}{l}\text { Herbometer } \\
\text { Hydraulic extractor, cooled } \\
\text { centrifuge, pH micro- } \\
\text { electrode etc. }\end{array}$ & $\begin{array}{l}\text { Site } 1 \text { (daily) } \\
\text { Site } 1 \text { (daily, selected diur- } \\
\text { nal profiles) }\end{array}$ & $\begin{array}{l}\text { INRA } \\
\text { UoC, FAL-CH, CEH } \\
\text { (Husted et al., 2000; Matts- } \\
\text { son et al., 2009a) }\end{array}$ \\
\hline \multirow[t]{5}{*}{ Soil measurements } & Soil moisture & $\begin{array}{l}\text { Time Domain Reflectome- } \\
\text { try }\end{array}$ & Site 1 Site $?$ & $\begin{array}{l}\text { Univ. Bonn (Imko Trime- } \\
\text { T3 tube access probe, www. } \\
\text { imko.de) }\end{array}$ \\
\hline & Soil profile (1) & $\begin{array}{l}\text { Gravimetric determınations } \\
\text { Classical soil assessment }\end{array}$ & $\begin{array}{l}\text { Site } 1 \text {, Site } 2 \\
\text { Site } 1\end{array}$ & $\begin{array}{l}\text { KISSAC, FAL-D } \\
\text { RISSAC }\end{array}$ \\
\hline & $\begin{array}{l}\text { Soil temperature and soil } \\
\text { heat flux (2) }\end{array}$ & $\begin{array}{l}\text { Part of Campbell "Bowen } \\
\text { Ratio System" measure- } \\
\text { ments }\end{array}$ & Site 1 & $\begin{array}{l}\text { ELU, CEH (Campbell } \\
\text { Scientific, Loughborough, } \\
\text { UK). }\end{array}$ \\
\hline & Soil available $\mathrm{NH}_{4}^{+}$and & Extracts in $\mathrm{KCl}$ & Site 1 & UoC, INRA \\
\hline & $\begin{array}{l}\text { Soil bulk density and other } \\
\text { physical measurements. }\end{array}$ & Range of methods & Site 1 and map of site & INRA (see Table 1) \\
\hline
\end{tabular}

Ample soil moisture was available for plant growth, due to the prior irrigation and rain events at several times during the experiment. Figure 11 shows the time course of volumetric soil water content, with values in the range 10-18\% vol. according to TDR measurements at $0.15 \mathrm{~m}$, and $12-$ $20 \%$ vol. by gravimetric determination for $0-0.1 \mathrm{~m}$, with a similar range from theta probe measurements. These values represent $46-91 \%$ of field capacity (Table 1), with averages of $63 \%$ (TDR) and $73 \%$ (gravimetric) field capacity for the experiment. The moisture content at $0.1-0.3 \mathrm{~m}$ was only slightly higher at $66 \%$ (TDR, $0.3 \mathrm{~m}$ ) and $76 \%$ field capacity (gravimetric, $0.1-0.3 \mathrm{~m}$ ). The TDR results are considered the more reliable and outlier gravimetric results ( $>$ field capacity) for wet conditions on 23 May are excluded from these means. TDR values for the $\mathrm{C} 1$ horizon were in the range 12.8-16.5, representing 77-99\% field capacity.

A survey of soil moisture across the field (theta probe, 0 $0.1 \mathrm{~m}$ depth, $50 \mathrm{~m}$ intervals, 3-4 June) showed no major E$\mathrm{W}$ gradients $(11.5 \pm 2.5 \%$ vol., $\pm \mathrm{SD})$, although the field was slightly drier at the N edge of Kleinkamp, E of Site 1, and at the $\mathrm{S}$ edge, $\mathrm{E}$ of the DWD. This did not significantly affect the flux foot-prints of Sites 1 and 2, but resulted in a slightly drier soil (9.4\% vol.) at Site 4.

The cutting and fertilization had major effects on the plant and soil $\mathrm{N}$ status conditions, providing a significant perturbation for $\mathrm{NH}_{3}$ exchange processes. Figure 11 shows that cutting the sward had no significant effect on soil $\mathrm{NH}_{4}^{+}$, although soil $\mathrm{NO}_{3}^{-}(0-0.1 \mathrm{~m})$ increased from 5 to $18 \mathrm{mg} \mathrm{N} \mathrm{g}^{1}$ dry soil after 4-5 days, with a smaller increase for $0.1-$ $0.3 \mathrm{~m})$. Much larger responses were recorded following fertilization, with soil $\mathrm{NH}_{4}^{+}$and $\mathrm{NO}_{3}^{-}(0-0.1 \mathrm{~m})$ increasing to 139 and $146 \mathrm{mg} \mathrm{N} \mathrm{g}^{-1}$ dry soil, respectively, 3 days after fertilization. The decrease by 10 June may be due to plant up- take and microbial immobilization, while rain later on 10-11 June may have led to remobilization, increasing $\mathrm{NH}_{4}^{+}$and $\mathrm{NO}_{3}^{-}$values on 12-14 June. Even 9 days after fertilization, a strong vertical profile was present, with $\sim 200 \mathrm{mg} \mathrm{N} \mathrm{g}^{-1}$ each of $\mathrm{NH}_{4}^{+}$and $\mathrm{NO}_{3}^{-}$for the layer $0-0.02 \mathrm{~m}$. This contrasts with 1 June where there was little gradient in the layer $0-0.1 \mathrm{~m}$.

While there was little effect of cutting on available soil $\mathrm{N}$, a clearer effect was recorded for total $\mathrm{N}$ content of grass foliage. Before cutting, the mature leaves contained $2.0 \% \mathrm{~N}$, and, where the grass was left uncut and unfertilized, this decreased slightly to $1.8 \%$. By contrast, the short re-growing sward $(0.13-0.18 \mathrm{~m})$ measured on $2-4$ June had a $\mathrm{N}$ content of $3.0-3.4 \% \mathrm{~N}$, presumably to $\mathrm{N}$ re-mobilization within the cut plants. Foliar $\mathrm{N}$ increased further following fertilization, with the values representing a balance between the effects of soil $\mathrm{N}$ uptake and growth dilution. A further increase occurred following the rain and increased soil $\mathrm{N}$ mobilization after 10 June.

\section{Discussion and conclusions}

This paper has introduced the rationale, questions and objectives of the GRAMINAE Braunschweig Experiment. It has described the strategy taken to address these multiple objectives in an integrated way, the nature of the measurements made, and the environmental, plant and soil conditions achieved during the experiment.

Integration is one of the key challenges in understanding environmental processes. Because there are so many interactions, addressing them necessarily increases the scale of the required effort. At the same time, increasing the number of interlinked objectives leads to the danger that the conditions 
A.
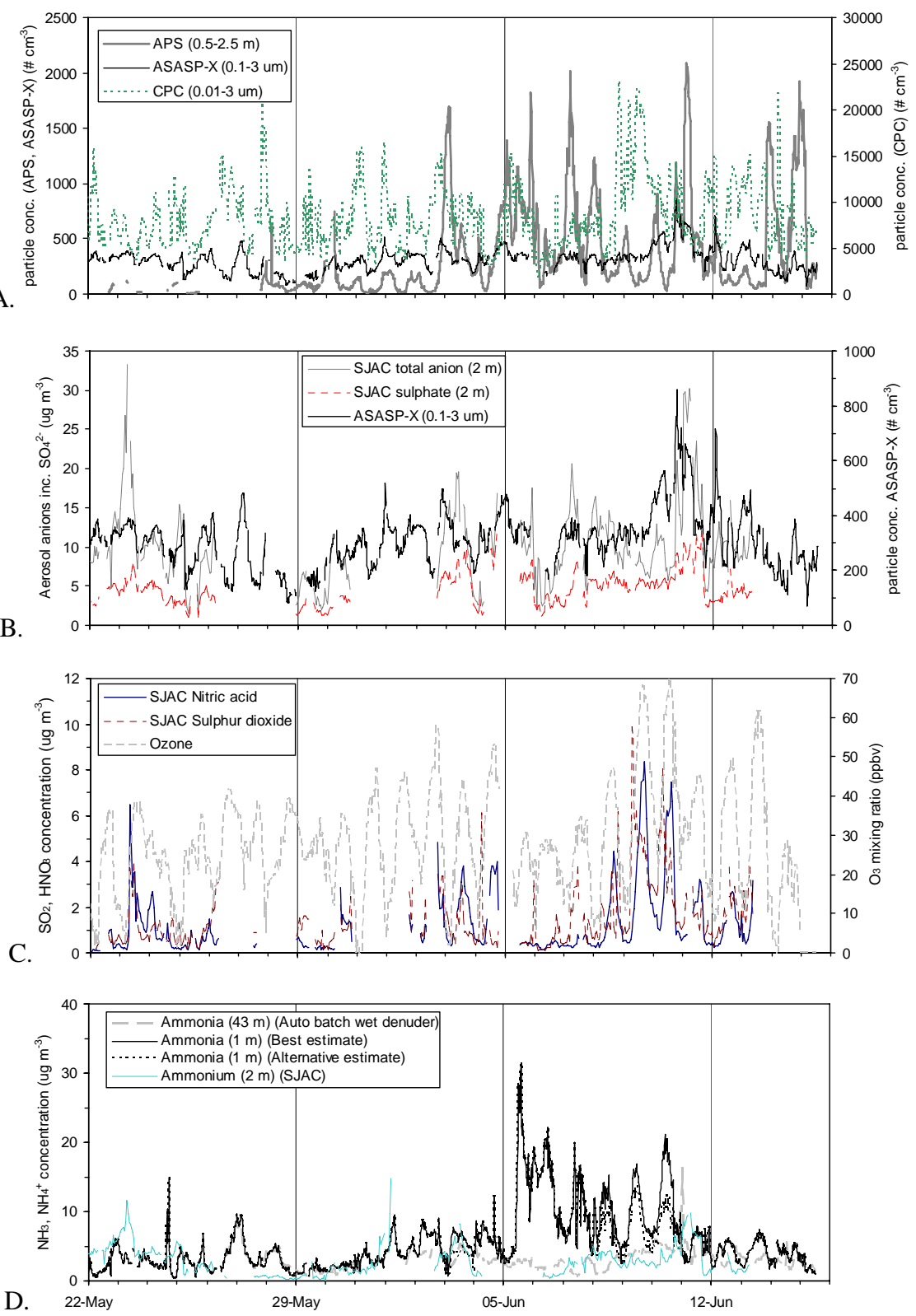

Fig. 8. Air concentrations of particles and mixing ratios of gases during the GRAMINAE Braunschweig Experiment. (a) Aerodynamic Particle Sizer (APS) (2.5 m); Condensation Particle Counter (CPC) (2 m); Axially Scattering Aerosol Spectrometer Probe (ASASP-X) (mean of 2 instruments at 0.7 and $2.9 \mathrm{~m}$ ). (b) Steam Jet Aerosol Collector (SJAC), including $\mathrm{SO}_{4}^{2-}, \mathrm{NO}_{3}^{-}, \mathrm{Cl}^{-}$and $\mathrm{NO}_{2}^{-}(2 \mathrm{~m})$; ASASP-X overlain for comparison. (c) $\mathrm{SO}_{2}$ and $\mathrm{HNO}_{3}$ by denuder linked to SJAC (mean of $0.3,2 \mathrm{~m}$ ); Ozone (5 km south of field site). (c) $\mathrm{NH}_{3}$ by automatic batch wet denuder (with off-line analysis) at Site 6; Best estimate $\mathrm{NH}_{3}$ derived $(1 \mathrm{~m}$ ) vertical profiles of 4 gradient continuous denuders; Alternative $\mathrm{NH}_{3}$ estimate $(1 \mathrm{~m})$, reflects uncertainty in selected denuders at certain times (Milford et al., 2008); $\mathrm{NH}_{4}^{+}$by SJAC as in (b).

required to meet some objectives may compromise others. Careful design of the GRAMINAE experiment was therefore essential. In particular, some would say that it is unwise to address advection issues in an experiment that also examines sources and sinks, net $\mathrm{NH}_{3}$ biosphere/atmosphere exchange and its interactions with aerosol chemistry. However, this misses the challenge faced: that these are real world issues to be addressed rather than avoided.
To allow consideration of advection effects, distances were therefore selected based on the prior modeling (Sect. 3.1) so that these would not dominate fluxes. In addition, it was recognized that advection effects would only occur for selected wind directions during the experiment. By contrast to the potential for conflict, addressing multiple questions also has the benefit that the researcher cannot anticipate which measurements will be least and most successful. 


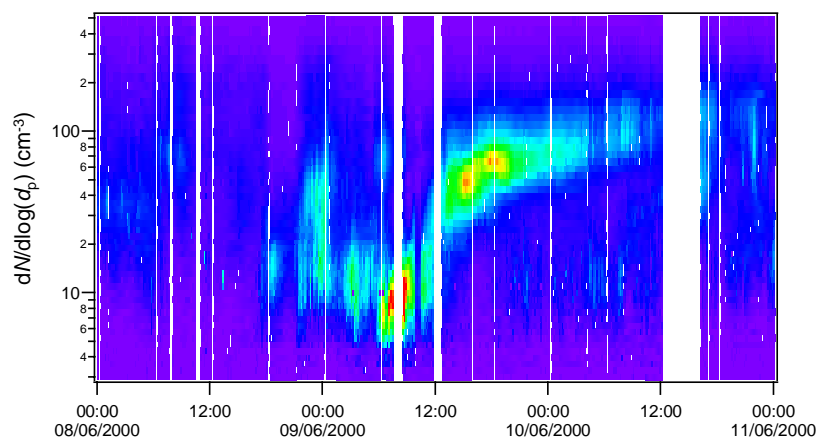

Fig. 9. Changing particle diameter $\left(d_{p}, \mathrm{~nm}\right)$ distribution from the Differential Mobility Particle Sizer (DMPS) during a regional nucleation event following a period of clean air from the SE on 810 June 2000. Increasing particle numbers $(N)$, represented as blue to green to red, are expressed as $\mathrm{d} N / \mathrm{d} \log \left(d_{p}\right)\left(\mathrm{cm}^{-3}\right)$.
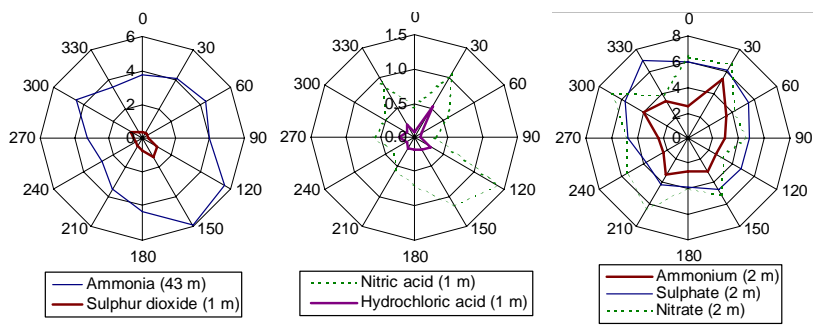

Fig. 10. Dependence of hourly gas mixing ratios (ppbv) and aerosol concentrations $\left(\mu \mathrm{g} \mathrm{m}^{-3}\right)$ on local wind direction $(10 \mathrm{~m})$ during the GRAMINAE experiment (22 May-15 June). Methods as in Fig. 8. The $\mathrm{N}$ sector $320^{\circ}-40^{\circ}$ is less certain for $\mathrm{SO}_{4}^{2-}, \mathrm{NO}_{3}^{-}, \mathrm{HNO}_{3}$ and $\mathrm{HCl}$ with $<30 \mathrm{~h}$ of data. Based on between $281\left(\mathrm{SO}_{2}\right)$ to $420\left(\mathrm{NH}_{3}\right)$ hours of measurement.

The basic site conditions presented here of synoptic meteorology, micrometeorological conditions, air chemistry, soil and plant conditions, show that the experimental set up was successful in obtaining a wide range of conditions to assess $\mathrm{NH}_{3}$ exchange processes. Firstly, the prevailing meteorology provided the range of turbulence, temperatures, wetness needed to address the interaction of plant physiological, leaf surface and canopy exchange processes. Secondly, different air mass origins provided a range of air chemistry, including conditions for both formation and evaporation of $\mathrm{NH}_{4}^{+}$ aerosol, while varying local wind direction allowed comparison of periods with and without $\mathrm{NH}_{3}$ significant advection errors in the vertical fluxes. Thirdly, the management of the main field and the management treatments provided a major perturbation to the grassland $\mathrm{N}$ cycling, allowing the processes of $\mathrm{NH}_{3}$ fluxes to be investigated in great detail.

The present paper provides the necessary background and introduction to the resulting series of papers arising from the experiment, presented in this special issue. A logical overview of the different paper contributions is provided in Fig. 12. These can be considered in four groups: 1) Mi-

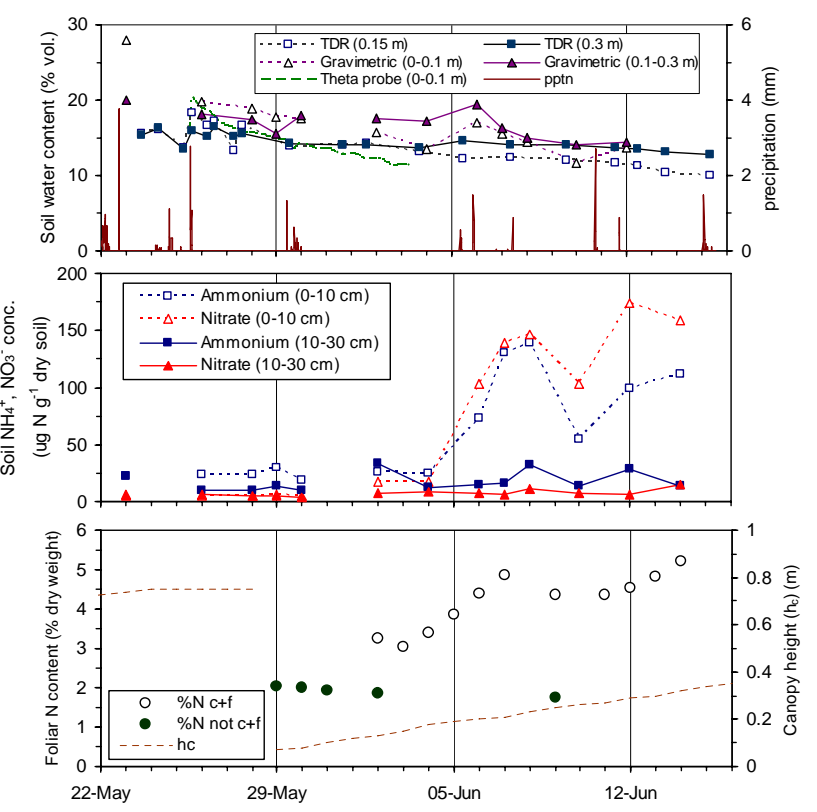

Fig. 11. Summary of soil moisture, available soil $\mathrm{N}$ and plant $\mathrm{N}$ during the GRAMINAE Integrated Experiment. Volumetric soil moisture content was measured different depths by TDR (Time Domain Reflectometry), gravimetric measurement and a Theta capacitance probe. Precipitation is shown on a 15 min basis. Soil ammonium and nitrate were determined following extraction in $2 \mathrm{M}$ $\mathrm{KCl}$. Total nitrogen content is shown for plants $(0.07-0.3 \mathrm{~m}$ height) in the main field $(\mathrm{c}+\mathrm{f})$ following cutting (29 May) and fertilizing (5 June), and for plants (0.75-0.8 m height) which were left uncut and unfertilized (not $\mathrm{c}+\mathrm{f})$.

crometeorology and net $\mathrm{NH}_{3}$ fluxes, 2) Biospheric controls, including within canopy turbulent exchange, 3) Interactions with acidic and other gases at the canopy surface, and 4) aerosol fluxes and $\mathrm{NH}_{3}$ gas-particle interactions.

\subsection{Micrometeorology and net $\mathrm{NH}_{3}$ fluxes}

The quantification of turbulent exchange fluxes and the energy balance is fundamental to any micrometeorological assessment. This is analyzed by Nemitz et al. (2009b), who use an inter-comparison of the different measurement systems applied to provide 'best estimates' of the exchange terms for the experiment. At the same time, they provide an assessment of the uncertainty in such measurements when (as in most studies) they are not replicated. Using these turbulent exchange estimates, Milford et al. (2008) compare the different AGM implementations for measurement of net $\mathrm{NH}_{3}$ fluxes, deriving both best estimates and uncertainties in the measured fluxes. Milford et al. thus provide a robust quantification of the response of $\mathrm{NH}_{3}$ exchange to environmental conditions and the grassland management events. These robust ammonia flux estimates by the AGM provide a reference for the assessment of four continuous REA systems for $\mathrm{NH}_{3}$ by Hensen et al. (2008). 


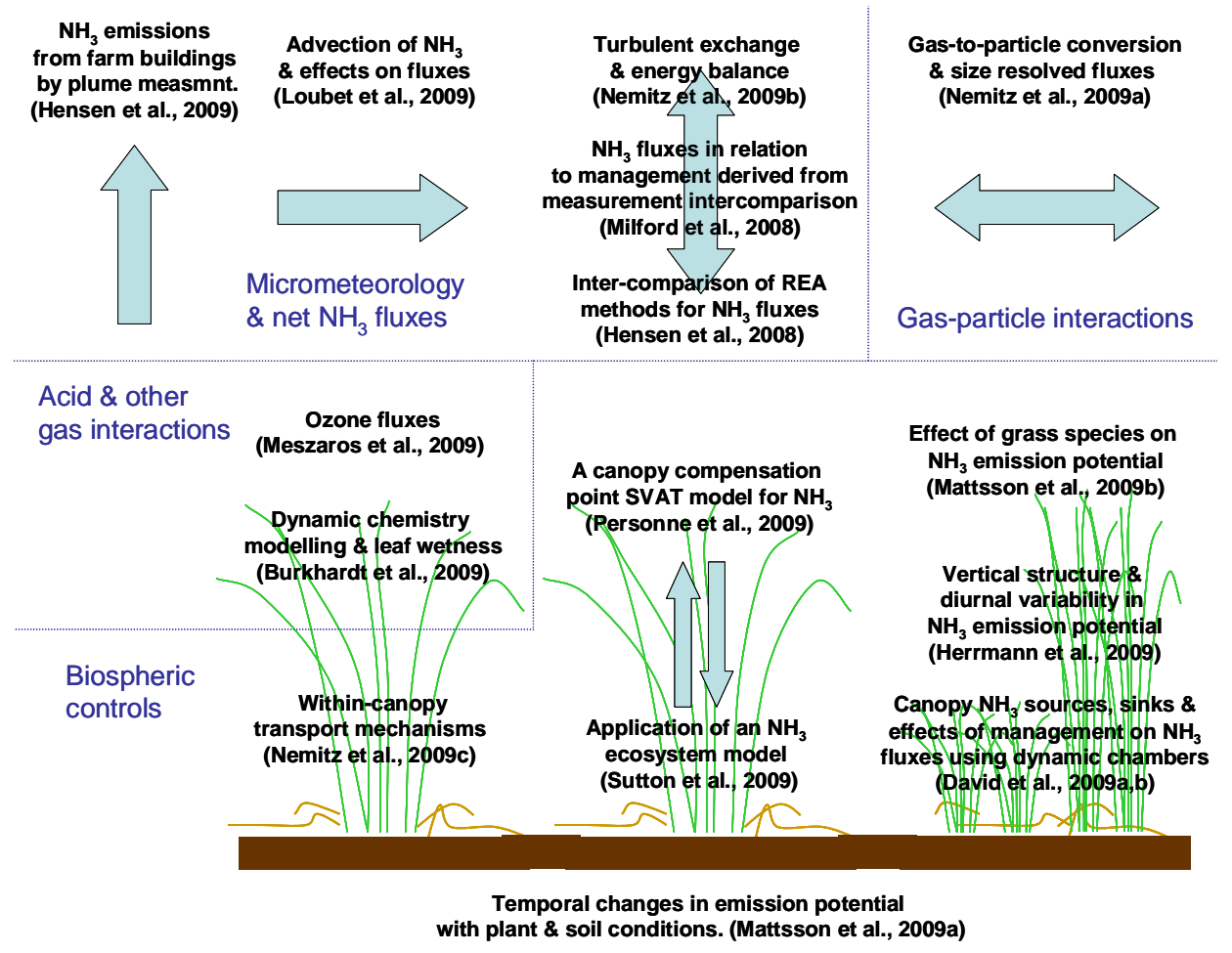

Fig. 12. Overview of the specific analyses emerging from the GRAMINAE Integrated Experiment that contribute to this Special Issue.

Two papers address $\mathrm{NH}_{3}$ emission from the adjacent FAL farm. Firstly, Hensen et al. (2009) apply the plume $\mathrm{NH}_{3}$ measurements to estimate the farm $\mathrm{NH}_{3}$ emissions, in comparison with the inventory approach. Secondly, Loubet et al. (2009) apply the $\mathrm{NH}_{3}$ concentrations measured at Sites 1, 2 and 3 in a Lagrangian stochastic dispersion model (MODDAS) to quantify the effects of the farm, and the emitting field itself, on advection errors in measured vertical fluxes.

\subsection{Biospheric controls on $\mathrm{NH}_{3}$ exchange}

The bioassay measurements of potential for $\mathrm{NH}_{3}$ emission are reported by Mattsson et al. (2009a, b) and Hermann et al. (2009). The interaction of plant $\mathrm{N}$ bioassays with changing soil conditions through the experiment, including determination of $\Gamma_{s}$ from apoplastic extractions, is presented by Mattsson et al. (2009a). Hermann et al. (2009) then report on vertical changes within the plant canopy, while Mattsson et al. (2009b) describe the inter-species differences in plant $\mathrm{N}$ bioassays and $\mathrm{NH}_{3}$ emission potential.

The effects of the grassland management options on bioassays are reported by Mattsson et al. (2009a), while David et al. (2009b) address the effects on net $\mathrm{NH}_{3}$ fluxes using the cuvette approach. David et al. (2009a) also use this approach to investigate the nature of the $\mathrm{NH}_{3}$ sources and sinks within the grass canopy. The cuvette approach is complemented by the investigation of within-canopy micrometeorology by $\mathrm{Ne}$ mitz et al. (2009c). Their investigation applies the measured vertical profiles of radon activity to estimate within-canopy exchange and estimates turbulent and heat exchange using measurements from a micro-sonic anemometer and hotwire anemometer located in the tall grass canopy. These approaches provide the basis to estimate within-canopy $\mathrm{NH}_{3}$ fluxes for selected periods.

The integration of biospheric and micrometeorological conditions in defining net $\mathrm{NH}_{3}$ fluxes is considered by Personne et al. (2009) and by Sutton et al. (2009). Firstly, Personne et al. apply the "canopy compensation point" resistance modelling approach (Sutton et al., 1995b; Nemitz et al., 2001b) to described the measured net $\mathrm{NH}_{3}$ fluxes, deriving stomatal resistances and values of $\Gamma_{s}, \Gamma_{\text {soil }}$ and the leaf cuticular uptake resistance for $\mathrm{NH}_{3}\left(R_{w}\right)$. Secondly, Sutton et al. (2009) apply the coupled grassland $\mathrm{C}-\mathrm{N}$ and $\mathrm{NH}_{3}$ exchange model, PASIM (Riedo et al., 2002) to the conditions of the experiment, comparing the results with the measured net $\mathrm{NH}_{3}$ fluxes. Together with the foregoing analyses, these examine the canopy scale trade-offs that define net $\mathrm{NH}_{3}$ fluxes.

\subsection{Interactions with acidic and other trace gases}

The performance of the profile SJAC system for measuring concentrations and fluxes of acidic and basic species is summarized by Nemitz et al. (2009a). The species measured included gaseous $\mathrm{SO}_{2}, \mathrm{HNO}_{3}, \mathrm{HCl}, \mathrm{HNO}_{2}, \mathrm{NH}_{3}$ and aerosol $\mathrm{SO}_{4}^{2-}, \mathrm{NO}_{3}^{-}, \mathrm{Cl}^{-}$and $\mathrm{NH}_{4}^{+}$. The availability of 
data on $\mathrm{NH}_{3}$, the acidic gases and aerosols, together with the results of dew chemistry sampling during the experiment allowed the leaf surface and flux interactions to be addressed by Burkhardt et al. (2009) using a canopy compensation point model that incorporates mixed chemistry dynamics on leaf surfaces (Flechard et al., 1999). In parallel, the measurements of $\mathrm{CO}_{2}$ and $\mathrm{O}_{3}$ exchange, and their relationship to grassland management are presented by Mészáros et al. (2009).

\subsection{Aerosol fluxes and $\mathrm{NH}_{3}$ gas - particle interactions}

The large $\mathrm{NH}_{3}$ emissions observed after fertilization of the grass, as well as the warm canopy temperatures, provide conditions with the potential for both formation/growth and evaporation of $\mathrm{NH}_{4}^{+}$-containing particles. Nemitz et al. (2009a) investigate the aerosol dynamics including the size resolved EC measurements of physical particle fluxes. They then combine these data with the results of the $\mathrm{NH}_{3}$ and $\mathrm{NH}_{4}^{+}$aerosol fluxes to assess the interactions between $\mathrm{NH}_{3}$ fluxes and gas-particle inter-conversion.

\subsection{Conclusions}

This introduction and the series of papers noted above demonstrates the multiple interactions that occur in defining net $\mathrm{NH}_{3}$ fluxes between the biosphere and atmosphere. The GRAMINAE Braunschweig experiment was designed to assess many of these in an integrated way, providing substantial synergy between different measurement groups and scientific issues being addressed. The experiment was successfully implemented with measurements over a 25-day period, covering a range of meteorological conditions and atmospheric chemistry, as well as plant and soil conditions associated with management perturbation of the grassland nitrogen cycle. It is shown how such an integrated strategy can be developed, which allows multiple objectives to be addressed through careful placement of sampling locations and timing of the different activities.

The detailed papers resulting provide the most comprehensive analysis of $\mathrm{NH}_{3}$ exchange processes that has been attempted to date. These cover issues of a) quantifying net $\mathrm{NH}_{3}$ fluxes in a real landscape and using new methods, b) the biospheric controls on $\mathrm{NH}_{3}$ fluxes, using a combination of flux measurement approaches, bioassays and models, c) the interactions that occur with acidic gases at the canopy surface, and d) the potential for $\mathrm{NH}_{3}$ fluxes to interact with particle fluxes within and immediately above a grassland canopy. The results of these detailed analyses are brought together at the end of this Special Issue in the synthesis presented by Sutton et al. (2009).

Acknowledgements. The authors gratefully acknowledge the support of many different funders and colleagues to this work. The measurements were conducted under the frame of the GRAMINAE project funded by the European Commission (DG Research), with input from a wide range of national funding agencies, in particular the UK Defra (AEQ Division). The final analysis of results was conducted under the EC NitroEurope Integrated Project, with travel support from the ESF NinE and COST 729 programmes.

Edited by: K. Pilegaard

\section{References}

Achermann, B. and Bobbink, R.: Empirical critical loads for Nitrogen (Report of UNECE Expert Workshop, Berne 11-13 November 2002). SAEFL, Berne, Switzerland, 2003.

Adams, P. J., Seinfeld, J. H., Koch, D., Micley, L., and Jacob, D.: General circulation assessment of direct radiative forcing by the sulfate-nitrate-ammonium-water inorganic aerosol system, J. Geophys. Res., 106(D1), 1097-1111, 2001.

Amann, M., Bertok, I., Cofala, J., Gyarfas, F., Heyes, C., Klimont, Z., Schöpp, W., and Winiwarter, W.: Baseline Scenarios for the Clean Air for Europe (CAFE) Programme. Final Report Contract No B4-3040/2002/340248/MAR/C1, IIASA, Laxenburg, Austria, (available at: www.iiasa.ac.at/rains/CAFE_files/ CAFE-baseline-full.pdf), 2005.

Armendariz, A. J. and Leith, D.: Concentration measurement and counting efficiency for the aerodynamic particle sizer 3320 , J. Aerosol Sci., 33(1), 133-148, 2002.

Brost, R. A., Delany, A. C., and Huebert, B.J.: Numerical modeling of concentrations and fluxes of $\mathrm{HNO}_{3}, \mathrm{NH}_{3}$, and $\mathrm{NH}_{4} \mathrm{NO}_{3}$ near the surface, J. Geophys. Res., 93, 7137-7152, 1988.

Burkhardt, J. and Eiden, R. Thin water films on coniferous needles, Atmos. Environ., 28A, 2002-1019, 1994.

Burkhardt, J., Flechard, C. R., Gresens, F., Mattsson, M., Jongejan, P. A. C., Erisman, J. W., Weidinger, T., Meszaros, R., Nemitz, E., and Sutton, M. A.: Modelling the dynamic chemical interactions of atmospheric ammonia with leaf surface wetness in a managed grassland canopy, Biogeosciences, 6, 67-83, 2009.

Bussink, D. W., Harper, L. A., and Corre, W. J.: Ammonia transport in a temperate grassland. 2. Diurnal fluctuations in response to weather and management conditions, Agron. J., 88, 621-626, 1996.

Coe, H., Williams, P. I., McFiggans, G., Gallagher, M. W., Beswick, K. M., Bower, K. N., and Choularton, T.W.: Behaviour of ultrafine particles in continental and marime air masses at a rural site in the United Kingdom, J. Geophys. Res., 105, 26891-26905, 2000

Csík, A., Formán, B., Kugler, Sz., Mészáros, R., Sass, E., Tarczay, K., Torma, C., and Weidinger, T.: Meteorological and backtrajectory analysis for the GRAMINAE Integrated Experiment. Department of Meteorology Eötvös Loránd University, H-1117 Budapest, Pázmány Péter sétány 1/A, Hungary, 2000.

Dämmgen, U. and Webb, J.: The development of the EMEP/CORINAIR Guidebook with respect to the emissions of different nitrogen and carbon species from animal production, Agric. Ecosyst. Environ., 112, 241-248, 2005.

David, M., Loubet, B., Cellier, P., Mattsson, M., Schjoerring, J. K., Nemitz, E., Roche, R., Riedo, M., and Sutton, M. A.: Ammonia sources and sinks in an intensively managed grassland using dynamic chambers, Biogeosciences Discuss., 6, 1625-1655, 2009, http://www.biogeosciences-discuss.net/6/1625/2009/. 
David, M., Roche, R., Mattsson, M., Sutton, M. A., Dmmgen, U., Schjoerring, J. K., and Cellier, P.: The effects of management on ammonia fluxes over a cut grassland as measured by use of dynamic chambers, Biogeosciences Discuss., 6, 1599-1623, 2009, http://www.biogeosciences-discuss.net/6/1599/2009/.

Davidson, C. I., Phalen, R. F., and Solomon, P. A.: Airborne Particulate Matter and Human Health: A Review, Aerosol Sci. Tech., 39, 737-749, 2005.

Denmead, O. T., Freney, J. R., and Simpson, J. R.: A closed ammonia cycle within a plant canopy, Soil Sci. Biochem., 8, 161-164, 1976.

Denmead, O. T., Nulsen, R., and Thurtell, G. W.: Ammonia exchange over a corn crop, Soil Sci. Soc. Am. J., 42, 840-842, 1978.

Duyzer, J. H.: Dry deposition of ammonia and ammonium aerosols over heathland, J. Geophys. Res., 99, 18757-18763, 1994.

Eriksson, E.: Air and precipitation as sources of nutrients. Section G. in: Hanbuch der pflanzeneenahrang und Dungun. vol. 2, part 1, edited by: Liser, H. and Schatter, K., Springer Verlag, Berlin, 774-792, 1968.

Erisman, J. W. and Wyers, G. P.: Continuous measurements of surface exchange of $\mathrm{SO}_{2}$ and $\mathrm{NH}_{3}$ : implications for their possible interaction in the deposition process, Atmos. Environ., 27A, 1937-1949, 1993.

Erisman, J. W., Bleeker, A., Galloway, J., and Sutton, M. A.: Reduced nitrogen in ecology and the environment, Environ. Pollut. 150, 140-149, 2007.

Erisman, J. W., Mennen, M. G., Fowler, D., Flechard, C. R., Spindler, G., Grüner, A., Duyzer, J., Ruigrok, W., and Wyers, G. P.: Dry Deposition Monitoring in Europe, Water, Air Soil Pollut. Focus, 1, 17-27, 2001a.

Erisman, J. W., Otjes, R., Hensen, A., Jongejan, P., van den Bulk, P., Khlystov, A., Möls, H., and Slanina, S.: Instrument development and application in studies and monitoring of ambient ammonia, Atmos. Environ. 35, 1913-1922, 2001 b.

Famulari, D., Fowler, D., Hargreaves, K., Milford, C., Sutton, M. A., Nemitz, E., and Weston, K.: Measuring eddy-covariance fluxes of ammonia using tunable diode laser absorption spectroscopy, Water, Air Soil Pollut., Focus, 4(6), 151-158, 2004.

Farquhar, G. D., Firth, P. M., Wetselaar, R., and Wier, B.: On the gaseous exchange of ammonia between leaves and the environment: determination of the ammonia compensation point, Plant Physiol., 66, 710-714, 1980.

Ferm, M. and Rodhe, H.: Measurements of air concentrations of $\mathrm{SO}_{2}, \mathrm{NO}_{2}$ and $\mathrm{NH}_{3}$ at rural and remote sites in Asia, J. Atmos. Chem., 27, 17-29, 1997.

Flechard, C., Fowler, D., Sutton, M. A., and Cape J. N.: Modelling of ammonia and sulphur dioxide exchange over moorland vegetation, Q. J. Roy. Meteor. Soc., 125, 2611-2641, 1999.

Flechard, C. R. and Fowler, D.: Atmospheric ammonia at a moorland site. II: Long-term surface-atmosphere micrometeorological flux measurements, Q. J. Roy. Meteor. Soc, 124, 759-791, 1998.

Fowler, D., Cape, J. N., and Unsworth, M. H.: Deposition of atmospheric pollutants on forests, Phil. Trans. Roy. Soc. London. B, 324, 247-265, 1989.

Gallagher, M. W., Nemitz, E., Dorsey, J. R., Fowler, D., Sutton, M. A., Flynn, M., and Duyzer, J.: Measurements and parameterisations of small aerosol deposition velocities to grassland, arable crops and forest, Influence of surface rough- ness length on deposition, J. Geophys. Res., 107(D12), a154, doi:10.1029/2001JD000817, 2002.

Gallagher, M. W., Beswick, K. M., Duyzer, J., Westrate, H., Choularton, T. W., and Hummelshoj, P.: Measurements of aerosol fluxes to Speulder Forest using a micrometeorological technique, Atmos. Environ., 31, 359-373, 1997.

Gamey, D. M. and Pinnick, R. G.: Response characteristics of Particle Measuring Systems active scattering aerosol spectrometer probe (ASASP-X), Aerosol Sci. Technol., 2, 477-488, 1983.

Harper, L. A., Bussink, W. D., van der Meer, H. G., and Corré, W. J.: Ammonia transport in a temperate grassland: I. Seasonal transport in relation to soil fertility and crop management, Agron. J., 88, 614-621, 1996.

Harper, L. A., Denmead, O. T. and Sharpe, R. R.: Identifying sources and sinks of scalars in a corn canopy with inverse Lagrangian dispersion analysis II. Ammonia. Agric. For. Meteor., 104, 75-83, 2000.

Hensen, A., Loubet, B., Mosquera, J., van den Bulk, W. C. M., Erisman, J. W., Dämmgen, U., Milford, C., Löpmeier, F. J., Cellier, P., Mikuška, P., and Sutton, M. A.: Estimation of $\mathrm{NH}_{3}$ emissions from a naturally ventilated livestock farm using local-scale atmospheric dispersion modelling, Biogeosciences Discuss., 6, 825-862, 2009,

http://www.biogeosciences-discuss.net/6/825/2009/.

Hensen, A., Nemitz, E., Flynn, M., Blatter, A., Jones S. K., Sørensen, L. L., Hensen, B., Pryor, S., Jensen, B., Otjes, R. P., Cobussen, J., Loubet, B., Erisman, J. W., Gallagher, M. W., Neftel, A. and Sutton M. A.: Inter-comparison of ammonia fluxes obtained using the Relaxed Eddy Accumulation technique. Biogeosciences Discuss., 5, 3965-4000, 2008, http://www.biogeosciences-discuss.net/5/3965/2008/.

Herrmann, B., Mattsson, M., Jones, S. K., Cellier, P., Milford, C., Sutton, M. A., Schjoerring, J. K., and Neftel, A.: Vertical structure and diurnal variability of ammonia exchange potential within an intensively managed grass canopy, Biogeosciences, 6 , 15-23, 2009, http://www.biogeosciences.net/6/15/2009/.

Hertel, O., Skjøth, C. A., Lofstrøm, P., Geels, C., Frohn, L. M., Ellermann, T., and Madsen, P. V.: Modelling nitrogen deposition on a local scale - A review of the current state of the art, Environ. Chem., 3, 317-337, 2006.

Hill, P. W., Raven, J. A., Loubet, B., Fowler, D., and Sutton, M. A.: Comparison of gas exchange and bioassay determinations of the ammonia compensation point in Luzula sylvatica, (Huds.) Gaud. Plant Phys., 125, 476-487, 2001.

Horváth, L., Asztalos, M., Führer, E., Mészáros, R., and Weidinger, T.: Measurement of ammonia exchange over grassland in the Hungarian Great Plain, Agric. For. Meteor., 130, 282-298, 2005.

Husted, S., Hebbern, C. A., Mattsson, M., and Schjoerring, J. K.: A critical experimental evaluation of methods for determination of $\mathrm{NH}_{4}^{+}$in plant tissue, xylem sap and apoplastic fluid, Physiol. Plantarum, 109(2), 167-179, 2000b.

Husted, S., Schjoerring, J. K., Nielsen, K. H., Nemitz, E., and Sutton, M. A.: Stomatal compensation points for ammonia in oilseed rape plants under field conditions, Agric. For. Meteorol. (Ammonia Exchange Special Issue), 105(4), 371-383, 2000.

Jongejan, P. A. C., Bai, Y., Veltkamp, A. C., Wyers, G. P., and Slanina, J.: An automated field instrument for the determination of acidic gases in air, Intern. J. Environ. Analyt. Chem., 66(4), 241- 
251, 1997.

Keuken, M. P., Schoonebeek, C. A. M., van Wensveen-Louter, A., and Slanina, J.: Simultaneous sampling of $\mathrm{NH}_{3}, \mathrm{HNO}_{3}, \mathrm{HCl}$, $\mathrm{SO}_{2}$ and $\mathrm{H}_{2} \mathrm{O}_{2}$ by a wet annular denuder system, Atmos. Environ., 22, 2541-2548, 1988.

Khlystov, A., Wyers, G. P., and Slanina, J.: The steam-jet aerosol collector, Atmos. Environ., 29, 2229-2234, 1995.

Kruit, R. J. W., van Pul, W. A. J., Otjes, R. P., Hofschreuder, P., Jacobs, A. F. G., and Holtslag A. A. M.: Ammonia fluxes and derived canopy compensation points over non-fertilized agricultural grassland in The Netherlands using the new gradient ammonia-high accuracy-monitor (GRAHAM), Atmos. Environ., 41, 1271-1287, 2007.

Kugler, S., Horváth, L., and Machon, A.: Estimation of nitrogen balance between the atmosphere and Lake Balaton and a semi natural grassland in Hungary, Environ. Pollut., 154, 498-503, 2008.

Kulmala, M., Vehkamaki, H., Petajda, T., Dal Maso, M., Lauri, A., Kerminen, V. M., Birmil, W., and McMurry, P. H.: Formation and growth rates of ultrafine atmospheric particles: a review of observations, J. Aerosol Sci., 35(2), 143-176, 2004.

Langford, A. O., Fehsenfeld, F. C., Zachariassen, J., and Schimel D. S.: Gaseous ammonia fluxes and background concentrations in terrestrial ecosystems of the United States, Global Biogeochem. Cy., 6, 459-483, 1992.

Lehmann, B. E., Hehmann, M., Neftel, A., and Tarakanov, S. V.: Radon-220 calibration of near surface turbulent gas transport, Geophys. Res. Lett., 26(5), 607-610, 1999.

Loubet, B., Cellier, P., Milford, C., and Sutton, M. A.: A coupled dispersion and exchange model for short-range dry deposition of atmospheric ammonia, Q. J. Roy. Meteor. Soc., 132, 1733-1763, 2006.

Loubet, B., Milford, C., Hill, P. W., Tang, Y. S., Cellier, P., and Sutton M. A.: Seasonal variability of apoplastic $\mathrm{NH}_{4}^{+}$and $\mathrm{pH}$ in an intensively managed grassland, Plant and Soil, 238, 97-110, 2002.

Loubet, B., Milford, C., Sutton, M. A., and Cellier, P.: Investigation of the interaction between sources and sinks of atmospheric ammonia in an upland landscape using a simplified dispersionexchange model, J. geophys Res., 106, 24183-24195, 2001.

Loubet, B., Milford, C., Hensen, A., Dämmgen, U., Cellier, P., and Sutton, M. A.: Advection of ammonia over a pasture field, and its effect on gradient flux measurements, Biogeosciences Discuss., 6, 163-196, 2009, http://www.biogeosciences-discuss.net/6/163/2009/.

Massad, R. S., Loubet, B., Tuzeta, A., and Cellier, P.: Relationship between ammonia stomatal compensation point and nitrogen metabolism in arable crops: Current status of knowledge and potential modelling approaches, Environ. Pollut., 154, 390-403, 2008 .

Mattsson, M. and Schjoerring, J. K.: Dynamic and steady state responses of inorganic nitrogen pools and $\mathrm{NH}_{3}$ exchange in leaves of Lolium perenne and Bromus erectus to changes in root supply, Plant Physiol., 128, 742-750, 2002.

Mattsson, M. and Schjoerring, J. K.: Senescence-induced changes in apoplastic and bulk tissue ammonia concentrations of ryegrass leaves, New Phyt., 160(3) 489-499, 2003.

Mattsson, M., Herrmann, B., David, M., Loubet, B., Riedo, M., Theobald, M. R., Sutton, M. A., Bruhn, D., Neftel, A., and
Schjoerring, J. K.: Temporal variability in bioassays of the stomatal ammonia compensation point in relation to plant and soil nitrogen parameters in intensively managed grassland, Biogeosciences, 6, 171-179, 2009a, http://www.biogeosciences.net/6/171/2009/

Mattsson, M., Herrmann, B., Jones, S., Neftel, A., Sutton, M. A., and Schjoerring, J. K.: Contribution of different grass species to plant-atmosphere ammonia exchange in intensively managed grassland, Biogeosciences, 6, 59-66, 2009b, http://www.biogeosciences.net/6/59/2009/.

Meixner, F. X., Ammann, C., Arenz, R., Nathaus, F. J., Neftel, A., Blatter, A., Gut, A., Hoegger, D., Wyers, G.P., Jongejan, P., Loesch, R., Busch, J., Guesten, H., Sprung, D., and Baumann, M.: The Bellheim '95 experiment: bi-directional fluxes of ammonia, Annales Geophysicae 14, Suppl II, C467, 1996.

Mészáros, R., Horváth, L. Weidinger, T., Neftel, A., Nemitz, E., Dämmgen, U., Cellier, P., and Loubet, B.: Measurement and modelling ozone fluxes over a cut and fertilised grassland, Biogeosciences Discuss., 6, 1069-1089, 2009, http://www.biogeosciences-discuss.net/6/1069/2009/.

Meyers, T. P., Luke, W. T. and Meisinger, J. J.: Fluxes of ammonia and sulfate over maize using relaxed eddy accumulation. Agric. For. Meteor. 136, 203-213, 2006.

Milford, C., Hargreaves, K. J., Sutton, M. A., Loubet, B., and Cellier P.: Fluxes of $\mathrm{NH}_{3}$ and $\mathrm{CO}_{2}$ over upland moorland in the vicinity of agricultural land, J. geophys Res. Atmos., 106, 24169-24181, 2001a

Milford, C., Theobald, M. R., Nemitz, E., and Sutton, M. A.: Dynamics of ammonia exchange in response to cutting and fertilizing in an intensively-managed grassland, Water, Air Soil Pollut. Focus, 1, 167-176, 2001b.

Milford, C., Theobald, M. R., Nemitz, E., Hargreaves, K. J., Horvath, L., Raso, J., Dämmgen, U., Neftel, A., Jones, S. K., Hensen, A., Loubet, B., Cellier, P., and Sutton, M. A.: Ammonia fluxes in relation to cutting and fertilization of an intensively managed grassland derived from an inter-comparison of gradient measurements, Biogeosciences Discuss., 5, 4699-4744, 2008, http://www.biogeosciences-discuss.net/5/4699/2008/.

Misselbrook, T. H., Nicholson, F. A., Chambers, B. J., and Johnson, R. A.: Measuring ammonia emissions from land applied manure: an intercomparison of commonly used samplers and techniques, Environ. Pollut., 135, 389-397, 2005.

Mosquera, J., Hensen, A., van den Bulk, W. C. M., Vermeulen, A T., and Erisman, J. W.: Long-term $\mathrm{NH}_{3}$ flux measurements above grasslands in the Netherlands. Water, Air Soil Pollut. Focus, 1(56), 203-212, 2001.

Neftel, A., Blatter, A., Gut, A., Hoegger, D., Meixner, F. X., Ammann, C., and Nathaus, F. J.: $\mathrm{NH}_{3}$ soil and soil surface gas measurements in a triticale wheat field, Atmos. Environ., 32(3), 499_ 506, 1998

Neftel, A., Blatter, A., Otjes, R., Erisman, J. W., and Hansen, A. State of the art REA NH${ }_{3}$ flux measurements. in: Proc. 10th Nitrogen Workshop, Copenhagen, August 1999. II.49. Royal Veterinary and Agricultural University, Copenhagen, 1999.

Neirynck, J. and Ceulemans, R.: Bidirectional ammonia exchange above a mixed coniferous forest, Environ. Pollut., 154, 424-438, 2008.

Nemitz, E. and Sutton, M. A.: Gas-particle conversions above a Dutch heathland: III. Modelling of size-dependent $\mathrm{NH}_{4}^{+}$fluxes 
as modified by the $\mathrm{NH}_{3}-\mathrm{HNO}_{3}-\mathrm{NH}_{4} \mathrm{NO}_{3}$ equilibrium, Atmos. Chem. Phys., 4, 1025-1045, 2004,

http://www.atmos-chem-phys.net/4/1025/2004/.

Nemitz, E., Flynn, M., Williams, P. I., Milford, C., Theobald, M. R., Blatter, A., Gallagher, M. W., and Sutton, M. A.: A relaxed eddy accumulation system for the automated measurement of atmospheric ammonia fluxes. Water, Air Soil Pollut. Focus, 1, 189202, 2001a.

Nemitz, E., Milford, C., and Sutton, M. A.: A two-layer canopy compensation point model for describing bi-directional biosphere/atmosphere exchange of ammonia, Q. J. Roy. Meteor. Soc., 127, 815-833, 2001b.

Nemitz, E., Sutton, M. A., Gut, A., San José, R., Husted, S., and Schjoerring, J. K.: Sources and sinks of ammonia within an oilseed rape canopy, Agr. For. Meteorol., 105(4), 385-404, 2000a.

Nemitz, E., Sutton, M. A., Schjoerring, J. K., Husted, S., and Wyers, G. P.: Resistance modelling of ammonia exchange over oilseed rape, Agr. For. Meteorol., 105(4), 405-425, 2000 b.

Nemitz, E., Sutton, M. A., Wyers, G. P., and Jongejan, P. A. C.: Gas-particle conversions above a Dutch heathland: I. Surface exchange fluxes of $\mathrm{NH}_{3}, \mathrm{SO}_{2}, \mathrm{HNO}_{3}$ and $\mathrm{HCl}$, Atmos. Chem. Phys., 4, 989-1005, 2004a,

http://www.atmos-chem-phys.net/4/989/2004/.

Nemitz, E., Sutton, M. A., Wyers, G. P., Mennen, M. G., van Putten, E. M., and Gallagher, M. W.: Gas-particle conversions above a Dutch heathland: II. Concentrations and surface exchange fluxes of atmospheric particles, Atmos. Chem. Phys., 4, 1007-1024, $2004 b$, http://www.atmos-chem-phys.net/4/1007/2004/.

Nemitz, E., Gallagher, M. W., Duyzer, J. H., and Fowler, D.: Micrometeorological measurements of particle deposition velocities to moorland vegetation, Q. J. Roy. Meteor. Soc., 128(585), 2281-2300, 2002.

Nemitz, E., Dorsey, J. R., Flynn, M. J., Gallagher, M. W., Hensen, A., Erisman J.-W., Owen, S.M., Dämmgen, U., and Sutton, M. A.: Aerosol fluxes and particle growth above managed grassland, Biogeosciences Discuss., 6, 341-389, 2009a,

http://www.biogeosciences-discuss.net/6/341/2009/.

Nemitz, E., Hargreaves, K. J., Neftel, A., Loubet, B., Cellier, P., Dorsey, J. R., Flynn, M., Hensen, A., Weidinger, T., Meszaros, R., Horvath, L., Dämmgen U., Fruehauf, C., Löpmeier F.J., Gallagher, M. W., and Sutton, M. A.: Inter-comparison and assessment of turbulent and physiological exchange parameters of grassland, Biogeosciences Discuss., 6, 241-290, 2009b, http://www.biogeosciences-discuss.net/6/241/2009/.

Nemitz, E., Loubet, B., Lehmann, B.E., Cellier, P., Neftel, A., Jones, S. K., Hensen A., Ihly B., Tarakanov S., and Sutton M. A.: Turbulence characteristics and transport mechanisms in grassland canopies, Biogeosciences Discuss., 6, 437-489, 2009c, http://www.biogeosciences-discuss.net/6/437/2009/.

NOAA: Manual of NOAA fast ozone sensor. NOAA Air Resources Laboratory, Atmospheric Turbulence and Diffusion Division, Oak Ridge, USA, 1996.

Oms, M. T., Jongejan, P. A. C., Veltkamp, A. C., Wyers, G. P., and Slanina, J.: Continuous monitoring of atmospheric $\mathrm{HCl}, \mathrm{HNO}_{2}$, $\mathrm{HNO}_{3}$, and $\mathrm{SO}_{2}$ by wet-annular denuder air sampling with online chromatographic analysis, Int. J. Environ. Anal. Chem., 62, 207-218, 1996.
Personne, E., Loubet, B., Herrmann, B., Mattsson, M., Schjoerring, J. K., Nemitz, E., Sutton, M. A., and Cellier, P.: SURFATM$\mathrm{NH}_{3}$ : a model combining the surface energy balance and the bi-directional exchanges of ammonia at the field scale, Biogeosciences Discuss., 6, 71-114, 2009,

http://www.biogeosciences-discuss.net/6/71/2009/.

Plantaz, M. A. H. G., Vermeulen, A. T., and Wyers, G. P.: Surface exchange of ammonia over grazed pasture, Chapter 9.8 in: Biosphere-atmosphere exchange of pollutants and trace substances, edited by: Slanina, J., 285-291, 1997.

Pryor, S. C., Barthelmie, R. J., Jensen, B., Jensen, N. O., and Sørensen, L. L.: $\mathrm{HNO}_{3}$ fluxes to a deciduous forest derived using gradient and REA methods, Atmos. Environ., 36, 5993-5999, 2002.

Riedo, M., Milford, C., Schmid, M., and Sutton, M. A.: Coupling soil-plant-atmosphere exchange of ammonia with ecosystem functioning in grasslands, Ecol. Model., 158, 83-110, 2002.

Schjoerring, J. K., Husted, S., and Mattsson, M.: Physiological parameters controlling plant-atmosophere ammonia exchange, Atmos. Environ., 32(3), 491-498, 1998.

Shaw, W. J., Spicer, C. W., and Kenny, D. V.: Eddy correlation fluxes of trace gases using a tandem mass spectrometer, Atmos. Environ., 32, 2887-2898, 1998.

Simpson, D., Fagerli, H., Jonson, J. E., Tsyro, S., Wind, P., and Tuovinen J.-P.: Transboundary acidification, eutrophication and ground level ozone in Europe, Part I, Unified EMEP Model description. 1, 1-104, Norwegian Meteorological Office, Blindern, 2006.

Söderlund, R. and Svensson, B. H.: The global nitrogen cycle. In: Nitrogen and Sulphur-Global Cycles, edited by: Svensson, B. H. and Söderlund, R., SCOPE report 7, Ecol. Bull. Stockholm, 22, 23-73, 1976.

Sørensen, L. L, Hertel, O., Ambelas Skjøth, C., Lund, M., and Pedersen, B.: Fluxes of ammonia in the coastal marine boundary layer, Atmos. Environ., 37, 167-177, 2003.

Spindler, G., Teichmann, U., and Sutton, M. A.: Ammonia Dry Deposition over Grassland: Micrometeorological Flux Gradient Measurements and Bi-directional Flux Calculations using an Inferential Model, Q. J. Roy. Meteor. Soc., 127, 795-814, 2001.

Sutton, M. A., Asman, W. A. H., and Schjørring, J. K.: Dry deposition of reduced nitrogen, Tellus, 46B, 255-273, 1994.

Sutton, M. A., Burkhardt, J. K., Guerin, D., Nemitz, E., and Fowler, D.: Development of resistance models to describe measurements of bi-directional ammonia surface atmosphere exchange, Atmos. Environ., 32(3), 473-480, 1998.

Sutton, M. A., Milford, C., Nemitz, E., Theobald, M. R., Hargreaves, K. J., Fowler, D., Schjoerring, J. K., Mattsson, M. E., Husted, S., Erisman, J. W., Otjes, R., Hensen, A., Mosquera, J., de Bulk, P., Jongejon, P., Mols, H., Cellier, P., Loubet, P., David, M., Roche, R., Durant, B., Laville, P., Neftel, A., Blatter, A., Hermann, B., Jones, S. K., Riedo, M., Horvath, L., Weidinger, T., Meszaros, R., Raso, J., Rajkai, K., Gallagher, M. W., Dorsey, J., Flynn, M., Lehmann, B., Burkhardt, J., and Daemmgen U.: GRAMINAE: Braunschweig Integrated Experiment - Intermediate Data. CD-ROM. CEH Edinburgh, 2001b.

Sutton, M. A., Milford, C., Nemitz, E., Theobald, M. R., Riedo, M., Hargreaves, K. J., Hill, P. W., Dragosits, U., Fowler, D., Schjoerring, J. K., Mattsson, M. E., Husted, S., Erisman, J. W., Hensen, A., Mosquera, J., Otjes, R., Cellier, P., Loubet, B., David, M., 
Neftel, A., Hermann, B., Jones, S. K., Blatter, A., Horvath, L., Weidinger, T., Meszaros, R., Raso, J., Mantzanas, K., Koukoura Z., Gallagher, M., Dorsey, J., Flynn, M., Lehman, B., Burkhardt, B., and Daemmgen, U.: Ammonia exchange with vegetation: measurement, modelling \& application. in: Transport and chemical transformation in the troposphere, edited by: Midgley, P. M. and Reuther, M., Margraf Verlag, Weikersheim, 49-60, 2002.

Sutton, M. A., Nemitz, E., Erisman, J. W., Beier, C., Butterbach Bahl, K., Cellier, C., de Vries, W., Cotrufo, F., Skiba, U., Di Marco, C., Jones, S., Laville, P., Soussana, J. F., Loubet, B., Twigg, M., Famulari, D., Whitehead, J., Gallagher, M. W., Neftel, A., Flechard, C., Herrmann, B., Calanca, P. L., Schjoerring, J. K., Daemmgen, U., Horvath, L., Tang, Y.S., Emmett, B. A., Tietema, A., Peñuelas, J., Kesik, M., Brueggemann, N., Pilegaard, K., Vesala, T., Campbell, C. L., Olesen, J. E., Dragosits, U., Theobald, M. R., Levy, P., Mobbs, D. C., Milne, R., Viovy, N., Vuichard, N., Smith, J. U., Smith, P.E., Bergamaschi, P., Fowler, D., and Reis, S.: Challenges in quantifying biosphereatmosphere exchange of nitrogen species, Environ. Pollut., 150, 125-139, 2007.

Sutton, M. A., Fowler, D., and Moncrieff, J. B.: The exchange of atmospheric ammonia with vegetated surfaces, I: Unfertilized vegetation, Quart. J. Roy. Meteor. Soc., 119, 1023-1045, 1993a.

Sutton, M. A., Fowler, D., Burkhardt, J. K., and Milford C.: Vegetation atmosphere exchange of ammonia: Canopy cycling and the impacts of elevated nitrogen inputs, Water, Soil Air Pollut., 85, 2057-2063, 1995a.

Sutton, M. A., Fowler, D., Moncrieff, J. B., and Storeton-West, R. L.: The exchange of atmospheric ammonia with vegetated surfaces, II: Fertilized vegetation, Q. J. Roy. Meteor. Soc., 119, 1047-1070, 1993b.

Sutton, M. A., Milford, C., Nemitz, E., Theobald, M. R., Hill, P. W., Fowler, D., Schjoerring, J. K., Mattsson, M. E., Nielsen, K. H., Husted, S., Erisman, J. W., Otjes, R., Hensen, A., Mosquera, J., Cellier, P., Loubet, B., David, M., Genermont, S., Neftel, A., Blatter, A., Herrmann, B., Jones, S. K., Horvath, L., Führer, E., Mantzanas, K., Koukoura, Z., Gallagher, M., Williams, P., Flynn, M., and Riedo, M.: Biosphere-atmosphere interactions of ammonia with grasslands: experimental strategy and results from a new European initiative, Plant Soil, 228, 131-145, 2001a.

Sutton, M. A., Nemitz, E., Fowler, D., Wyers, G. P., Otjes, R. P., Schjoerring, J. K., Husted, S., Nielsen, K., San José, R., Moreno, J., Gallagher, M. W., and Gut, A.: Fluxes of ammonia over oilseed rape: Overview of the EXAMINE experiment, Agric. For. Meteorol., 105(4), 327-349, 2000 b.

Sutton, M. A., Nemitz, E., Theobald, M. R., Milford, C., Dorsey, J. R., Gallagher, M. W., Hensen, A., Jongejan, P. A. C., Erisman, J. W., Mattsson, M. E., Schjoerring, J. K., Cellier, P., Loubet, B., Roche, R., Neftel, A., Hermann, B., Jones, S., Lehman, B. E., Horvath, L., Weidinger, T., Rajkai, K., Burkhardt, J., Löpmeier, F. J., and Daemmgen, U.: Dynamics of ammonia exchange with cut grassland: strategy and implementation of the GRAMINAE Integrated Experiment, Biogeosciences Discuss., 5, 3347-3407, 2008, http://www.biogeosciences-discuss.net/5/3347/2008/.

Sutton, M. A., Nemitz, E., Milford, C., Campbell, C., Erisman, J. W., Hensen, A., Cellier, P., David, M., Loubet, B., Personne, E., Schjoerring, J. K., Mattsson, M., Dorsey, J. R., Gallagher, M. W., Horvath, L., Weidinger, T., Meszaros, R., Dämmgen, U., Neftel,
A., Herrmann, B., Lehman, B. E., Flechard, C., and Burkhardt, J.: Dynamics of ammonia exchange with cut grassland: synthesis of results and conclusions of the GRAMINAE Integrated Experiment, Biogeosciences Discuss., 6, 1121-1184, 2009, http://www.biogeosciences-discuss.net/6/1121/2009/.

Sutton, M. A., Pitcairn, C. E. R., and Fowler, D.: The exchange of ammonia between the atmosphere and plant communities, Adv. Ecol. Research. 24, 301-393, 1993c.

Sutton, M. A., Schjørring, J. K., and Wyers, G. P.: Plant - atmosphere exchange of ammonia, Phil. Trans. Roy. Soc., London. Series A. 351, 261-275, 1995b.

Trebs, I., Lara, L. L., Zeri, L. M. M., Gatti, L. V., Artaxo, P., Dlugi, R., Slanina, J., Andreae, M. O., and Meixner, F. X.: Dry and wet deposition of inorganic nitrogen compounds to a tropical pasture site (Rondonia, Brazil), Atmos. Chem. Phys., 6, 447-469, 2006, http://www.atmos-chem-phys.net/6/447/2006/.

van Breemen, N, Burrough, P. A., Velthorst, E. J., van Dobben, H. F., de Wit, T., Ridder, T. B., and Reijnders, H. F. R. : Soil acidification from atmospheric ammonium sulphate in forest canopy throughfall, Nature, 299, 548-550, 1982.

Vayenas, D. V., Takahama, S., Davidson, C. I., and Pandis, S. N.: Simulation of the thermodynamics and removal processes in the sulfate-ammonia-nitric acid system during winter: Implications for $\mathrm{PM}_{2.5}$ control strategies, J. Geophys. Res. Atmos., 110(D7), D07S14, doi:10.1029/2004JD005038, 2005.

UNECE: Review of the 1999 Gothenburg Protocol. Report on the Workshop on Atmospheric Ammonia: Detecting Emission Changes and Environmental Impacts. ECE/EB.AIR/WG.5/2007/3, (available at: www.unece.org/ env/documents/2007/eb/wg5/ece.eb.air.wg.5.2007.3.e.pdf), 2007.

Walker, J. T., Robarge, W. P., Wuc, Y., and Meyers, T. P.: Measurement of bi-directional ammonia fluxes over soybean using the modified Bowen-ratio technique, Agric.For. Meteor., 138, 54$68,2006$.

Whitehead, J. D., Twigg, M., Famulari, D., Nemitz, E., Sutton, M. A., Gallagher, M. W., and Fowler, D.: Evaluation of laser absorption spectroscopic techniques for eddy covariance flux measurements of ammonia, Environ. Sci. Technol., 42(6), 2041-2046, 2008.

Williams, P. I.: Construction and validation of a DMPS for aerosol charaterization, PhD Thesis, University of Manchester Institute of Science and Technology, UK, 1999.

Wolff, V., Trebs, I., Ammann, C., Spierig, C., Flechard, C., Neftel, A., and Meixner, F. X.: Concentrations and fluxes of soluble reactive nitrogen compounds over an intensively managed grassland site, Geophys. Res. Abs., 9, 02906, 2007.

Wyers, G. P. and Erisman, J. W.: Ammonia exchange over coniferous forest. Atmos. Environ., 32(3), 441-451, 1998.

Wyers, G. P., Otjes, R. P., and Slanina, J.: A continuousflow denuder for the measurement of ambient concentrations and surface-exchange fluxes of ammonia, Atmos. Environ., 27, 2085-2090, 1993.

Zhu, T., Pattey, E., and Desjardins, R. L.: Relaxed eddyaccumulation for measuring ammonia volatilization, Environ. Sci. Technol., 34(1), 199-203, 2000. 